\title{
A Baláta-tó környezettörténete
}

\author{
SÜMEGI PÁL ${ }^{1,2}$, NÁFRÁDI KATALIN¹, JAKAB GUSZTÁV³ , PERSAITS GERGÖ¹ ÉS TÖRÖCSIK TÜNDE1 \\ ${ }^{1}$ Szegedi Tudományegyetem Földtani és Öslénytani Tanszék, H-6701 Szeged P. O. Box: 658., e-mail: sumegi@geo.u-szeged.hu \\ ${ }^{2}$ MTA Régészeti Intézet H-1014 Budapest Úri u. 49. \\ ${ }^{3}$ Sámuel Tessedik College, H-5540 Szarvas, Szabadság út 2.
}

Sümegi, P., Náfrádi, K., Jakab, G., Persaits, G. and Töröcsik, T.: The environmental history of Lake Baláta.

Abstract: Sedimentary basins such as Lake Baláta in Southwestern Hungary provide information about the development of lake-bog systems, the climate change through time and about the environment of the surrounding area.

The application of different methods, such as sedimentological, geochemical, macrofossil, pollen and charcoal analysis make it possible to reconstruct the climatic, vegetation and hydrological changes of this protected area for the last 3000 years. Lake Baláta is a sedimentary basin developed in a wind-blown yardang system. Due to its deeper location and the higher groundwater-level the boggy lake functioned as a sediment catchment basin. So by the analysis of samples derive form cores we get closer to the formation, development and the temporal changes of the environment of the lake-bog system.

Keywords: palaeoecology, macrobotany, pollen analysis, sedimentology, Baláta Lake

\section{Bevezetés}

Jelen dolgozat célja, hogy a környezettörténet eszközeit felhasználva egy dél-dunántúli tavi üledékgyűjtő, a Baláta-tó medencéjének feltárásával rekonstruáljuk, a tavi rendszerben és környezetében milyen paleohidrológiai - környezettörténeti változások játszódtak le az elmúlt évezredek során. Munkánk eredményeit arra is felhasználtuk, hogy felvázoljuk a napjainkban zajló éghajlati változások milyen növényzeti és hidrológiai átalakulásokat válthatnak ki a közeljövőben ezen a védett területen.

A Baláta-tó Belső-Somogyban, Kaszó (korábbi nevén Kaszópuszta) község határában, a Szentaierdőben egy futóhomok területen kialakult szélbarázda rendszerben fejlödött ki (1. ábra). Ezek a területre jellemző, mélyebben fekvő, talajvízzel borított szélbarázdákban (2. ábra) kifejlődött mocsaras, lápos, lápos

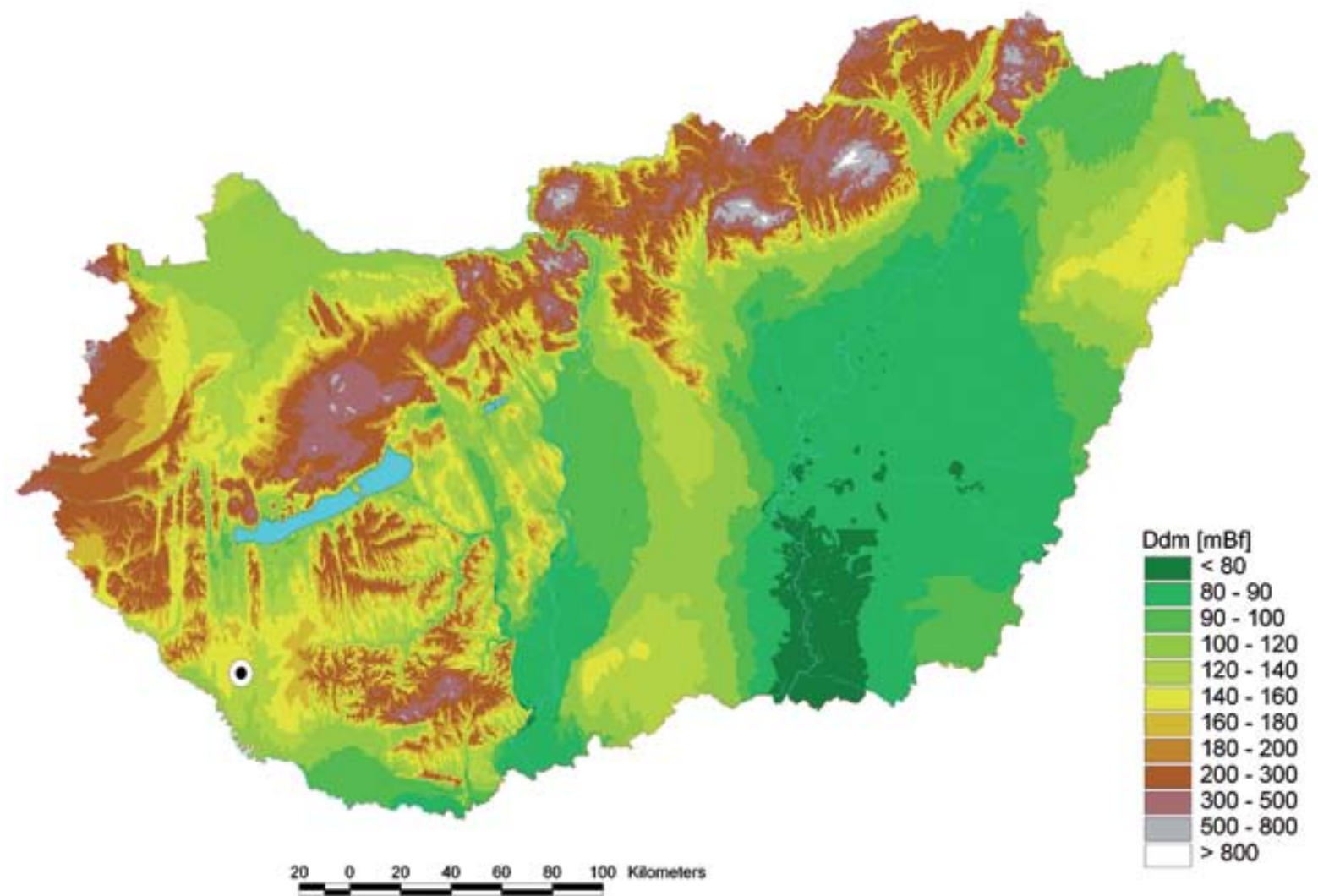

1. ábra: A Baláta-tó elhelyezkedése a Dunántúli déli részén.

Fig.1.: The position of the Baláta lake in SW Transdanubia (Hungary). 


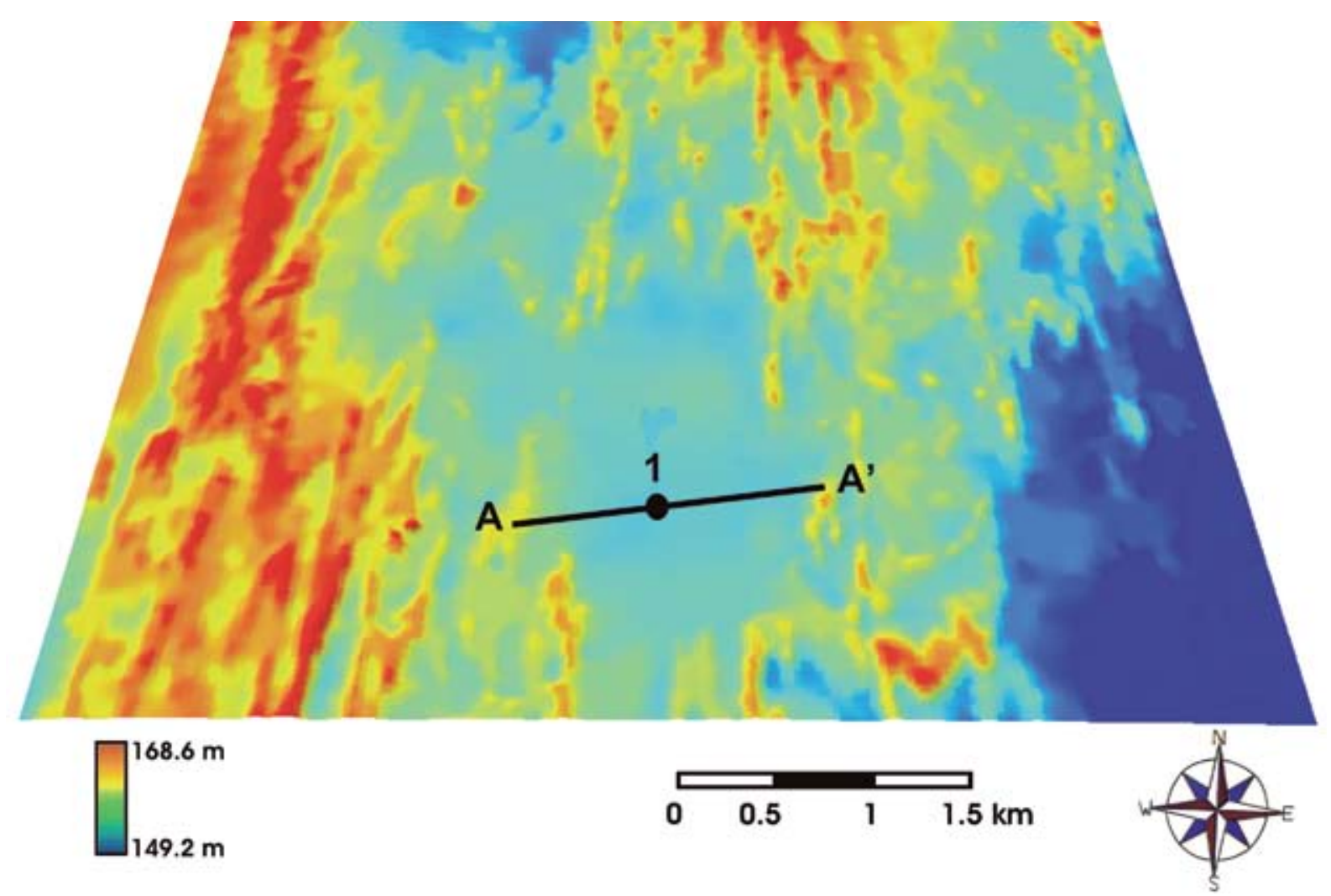

2. ábra: A Baláta-tó digitális domborzati modellje a keresztszelvénnyel és fúrásponttal (Persaits, 2007).

Fig.2.: DDM of the Baláta lake within geological cross-section line and the analyzed core-point.

tavi területek kialakulásuktól kezdődően üledékcsapdaként gyűjtötték a környezetükből származó üledékes anyagokat. Így az üledékgyűjtő medencékben, köztük a Baláta-tóban felhalmozódott rétegek feldolgozásával (3. ábra) közelebb kerülhetünk a terület kialakulásának, fejlődésének és a tavi környezet időbeli változásának megrajzolásához.

A cikkben központi helyet elfoglaló tavi rendszer és környezete fejlödéstörténetének felvázolásához, valamint a különböző üledékgyűjtő rendszerek feltáráshoz meg kell értenünk az üledékgyüjtő medencékben az üledék felhalmozódásának, a különböző ősmaradvány típusok beágyazódásának mechanizmusát, mert a negyedidőszaki paleoökológiai, régészeti geológiai, környezettörténeti kutatásokban jelentős szerepet tölt be a lokális felhalmozódási környezet, a kis területü üledékgyűjtő medencék rekonstrukciója (SüMEGI, 2001).

A különböző üledékgyűjtők a bennük megőrződött mikro- és makrofosszíliák, magának az üledéknek az elemzésével lehetőséget nyújtanak a vegetáció-, a talaj-, a faunafejlődés és az antropogén hatások helyi és regionális léptékű vizsgálatára (SüMEGI, 2003). Az egyik legpontosabb negyedidőszaki őskörnyezeti rekonstrukciós modellt az egykori környezet változásairól a tó és vízgyűjtő rendszerének kapcsolatánál dolgozták ki (MACKERETH, 1966, BIRKS-BIRKS, 1980).

A modell lényege az, hogy egy tó, láp vagy mocsár medrét és vízgyüjtő területét lehatárolják a vízgyüjtő geomorfológiai, illetve geológiai adottságai, a termé- szetes vízválasztó vonala, határai. A vízgyűjtő területéről származó anyagok, a lejtők alapkőzetéből, talajából lepusztult anyagok mosódhatnak, szél által szállított por és virágporszemek hordódhatnak be és rakódhatnak le távoli területekről az üledékgyűjtőbe, illetve a tóban élt szervezetekből is jelentős mennyiségü üledék képződhet és halmozódhat fel az aljzaton. Ezek az anyagok információt hordoznak a múltbeli környezeti változásokról.

Így ugyan az őskörnyezeti adatok egy-egy konkrét mintavételi hely (szelvény, fúráspont) üledékéböl származnak, de az ott felhalmozódott üledékek, ősmaradványok nem kizárólag egyetlen helynek, hanem a szélesebb értelemben vett üledékgyűjtő területén végbement folyamatoknak és az egykori környezetváltozásoknak őrzik meg a nyomait. Az eltérő származású anyagok egy helyen történő felhalmozódása azt jelenti, hogy az üledékgyűjtő térben is reprezentálja a vízgyűjtő, valamint a befogási területén végbement változásokat. Ugyanakkor a tavi, lápi vagy mocsári rendszerben található üledékrétegek felhalmozódása időfüggő esemény, ezért az üledékgyüjtő nemcsak a vízgyűjtő területen történt eseményeket gyűjti össze, hanem időben is rögzíti a felhalmozódott üledékek, és rétegek helyzetét.

Az erózió, szállítás és akkumuláció nyomán felhalmozódott üledékek, az üledékgyűjtő rendszerek a térben és időben történő őskörnyezeti változásaikról egyaránt információkat tartalmaznak. A felhalmozódott anyagokon végzett radiokarbon vagy más kormeghatározási módszerek segítségével a vízgyűjtő területén bekövet- 


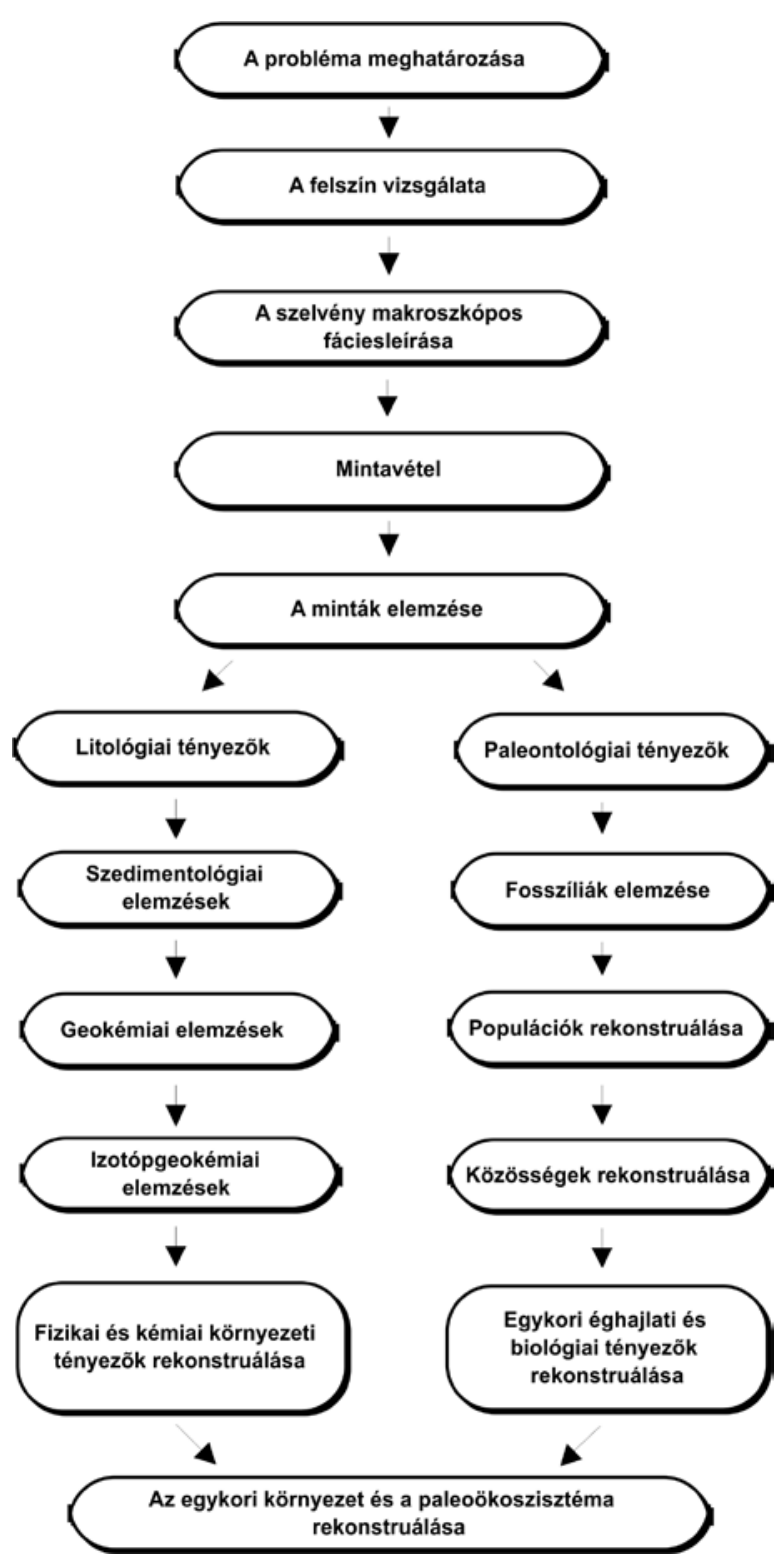

3. ábra: Negyedidőszaki paleoökológiai vizsgálatok menete (Birks-Birks, 1980 nyomán).

Fig.3.: The progress of the Quaternary Palaeoecological analyses (after Birks-Birks, 1980).

kezett üledékképződés, lepusztulás és felhalmozódás sebességéröl kaphatunk információkat. Amennyiben a mikroléptékű (néhány hektáros) skálán történő környezeti változásokat akarjuk megvizsgálni, akkor olyan kisebb felületű, zártabb üledékgyűjtő rendszereket kell kiválasztani, amelyek döntően a lokális, döntően néhány $\mathrm{km}^{2}$ kiterjedésü jelenségekről hordoznak információkat. Ilyen kisebb méretü, lokális üledékgyüjtőként fogható fel a Baláta-tó medre is.

\section{Kutatástörténet és a történeti források rövid áttekintése}

Általában Boros Ádám botanikust tartják a Balátató tudományos felfedezőjének, mert 1922-1925 közötti expedíciói során felfedezi a harmatfüfélékhez tartozó, rovaremésztő Aldrovanda vesculosa fajt 1924-ben. Mégis az első tudományos feldolgozása a területnek 1905-1909 közötti földtani térképezés volt, amelyet László Gábor geológus (és a tőzegek kémiai összetételét vizsgáló Emszt Kálmán) vezette és a láp vizsgálatának eredményeit már 1911 és 1915 között több publikációban, köztük egy magyar és német nyelvü monográfiában ismertette (László, 1911, 1913, 1915).

Dudich Endre, Éhik Gyula és Vásárhelyi István zoológusok végeztek kiemelkedő jelentőségű vizsgálatokat 1927-ben, megtalálták és közölték a keresztes vipera fekete színű változatát (Vipera berus var. prester). A terület természetvédelmi kezelését először Földvári Miksa erdőtanácsos javasolta 1928-1929-ben, majd 1942-ben rendeletben természetvédelmi területté nyilvánítják a Baláta tavat és környékét, de igazi védelme csak 1954-ben valósult meg, Marián Miklós zoológus és Szőllősi József Somogy-megyei erdészeti-vadászati felügyelő hathatós támogatásával.

Ugyanakkor tudnunk kell, hogy a láp természetes - természet közeli állapotban való fennmaradását a terület mindenkori birtokviszonyai és a természeti adottságai magyarázzák. A Baláta-tó és környéke a várral rendelkező, ispáni vezetésü segesdi királyi-királynői birtok része volt az Árpádkor végén. A segesdi birtok szerepe kiemelkedő jelentőségü az Árpádkori és különösen a XIII. századi magyar történelemben. A tatárokkal vívott Muhi csatában megsebesült Kálmán herceg innen menekül Dalmáciába, majd Hainburgból Zágrábba menekülő IV. Béla király is a segesdi birtokot érintve alakította ki útját (ZATYKó, 2007).

Az első említése a Baláta-tónak egy birtokadományozás és annak megerősítése kapcsán maradt fenn (ZATYKó, 2007). Ugyanis IV. László halála (1290) után Velencéből hazatérő III. András trónrakerülése után kirobbant mozgalmak során Kőszegi Henrik fia János III. András királyt és kíséretét Mosonnál elfogta, majd három hónapig zárva tartotta. A király kiszabadulásáért cserébe Tenguldy Tivadar alkancellár testvérét Lászlót és három unokaöccsét adta a Köszegiek fogságába. Tenguldy László szabadulásakor 200 márkát fizetett és saját fiát adta túszul, aki később a börtönben megbetegedett és meghalt. Hüségéért 1295-ben Thomasina királyné - III. András anyja, István herceg, II. András utószülött fia itáliai származású felesége megjutalmazta és a Segesd nevű prediumához tartozó Zub földet (Szob, ma: Somogyszob) adományozta neki. A 13. század vége előtt tehát Szob és mint az adomány 1330. évi megerősítéséből kiderül, a határába eső Baláta-tó is a segesdi királynéi uradalomhoz tartozott (ZATYKó, 2007).

Ettől kezdődően számos világi és egyházi főúr birtokolta a területet (pl.: Széchenyi család, Festetics család), az államosítás előtt 1945-ig Oehringen- 
Keresztély Hohenlohe német herceg tulajdonában volt, aki - mintegy 30 évi birtoklása alatt - mindent elkövetett a Baláta-tó zavartalanságának biztosítására. A hatalmas erdőség kizárólag a nagyvad-vadászat céljára szolgált. Utak az erdőben nem voltak, a nyiladékrendszer kialakítása csak a vadászat célkitüzéseinek megfelelően történt. A jelentős kiterjedésű zavartalan erdőségnél az is felmerült, hogy bölény telepítés színterévé válik, de ezt a lápos környezet miatt nem valósult meg. 1945-1950 között szovjet katonai (Szovjet Javak Igazgatóság) kezelésben volt a Kaszói-erdő és a Baláta-tó, 1950-től a Magyar Állami Erdészethez tartozott és - mint nagyvadas területet - vadászati rezervátummá minősítették és a Honvédelmi Minisztérium Kaszó Erdőgazdaság Rt kezelésébe utalták át, majd HM Kaszó Erdőgazdasági Rt és a Duna-Dráva Nemzeti Park kezelésében volt a terület, 2008-ban a védett területet kibővítették, erdőrezervátumnak és fokozottan védett területnek nyilvánították.

Mindebből kitünik, hogy a Kaszói-erdő és benne a Baláta-tó történelmünk során mindig valamely nagybirtok, vagy jelentős kiterjedésü üzemegység részét alkotta, ahol a fő cél a vadászat és erdőgazdálkodás volt, így a láp környékét szántóföldi - állattenyésztési területek kialakításával nem bolygatták. Ez jelentős védelmet biztosított a Baláta-tó számára. A lápos terület egyetlen alkalommal, a bölénytelepítési terveknél került veszélybe, mert ekkor a láp lecsapolását tervezték, de ez szerencsére elmaradt, így a terület az elmúlt 600-1100 év során az emberi hatásoktól viszonylag érintetlen maradhatott. 1954-től pedig a természetvédelem biztosítja a védelmét.

A természetvédelmi területen kialakított kutatások közül kiemelkedő jelentőségűek Marián Miklós gerinces zoológiai (MARIAN, 1957) és Kasza Ferenc ornitológus vizsgálatai (KASZA-MARIÁN, 2001), Borhidi Attila és Járainé-Komlódi Magda botanikai elemzései, vegetációtérképezései (BORHIDI-JÁRAINÉ KomLÓDI, 1959a,b, 1960, BoRHIDI, 1968, 1970), valamint a Somogy Megyei Múzeumok Igazgatósága által vezetett több évtizedes feltáró munka. Ez utóbbihoz kapcsolódik egy kísérlet a Baláta-tó fejlődéstörténetének feltárására, amely a Somogy Megyei Múzeum Igazgatósága megbízásából Dr. Fúköh Levente, a gyöngyösi Mátra Múzeum igazgatójának vezetésével történt, aki egy kutatási (OTKA) projekt részeként fúrásokat mélyített a területen. A fúrásokat vezető $D r$. Füköh Levente feljegyzései szerint a tőzeges réteg a balátai lápon nem vastagabb 10-20 cm-nél. Mivel a László Gábor vezette geológiai kutatások közel 100 évvel korábban még méteres kifejlődést jeleztek, ezért felmerült, hogy igen jelentős tőzegpusztulás alakulhatott ki a vizsgált lápon a XX. század folyamán.

A következő (OTKA) kutatási projekt Rudner Edina vezetésével történt (a kutató csoport tagjai voltak; Braun Mihály, Jakab Gusztáv, Magyari Enikő és Sümegi Pál) és a terület északi részéről történt fúrásmag kihozatal. A csónakról történt fúrás nyomán csak vékonyabb, paleoökológiai és környezettörténeti vizsgálatra kevésbé alkalmas, lakusztrikus és tőzeges réte- geket sikerült feltárni. Jakab Gusztáv makrobotanikus már ekkor jelezte, hogy az üledékgyüjtő medence déli részén talán jobbnak bizonyulhat a rétegsor, mert a területen uralkodó északi szelek keltette hullámmozgásoknak köszönhetően a makrobotanikai leletek döntő része a tó déli medencéjében halmozódhatott fel és ágyazódhatott be.

Jakab Gusztáv javaslata nyomán, az eddigi utolsó környezettörténeti kutatás során, egy NKTH projekt részeként 2004 január 15-17 és február 2-6 között tizennyolc zavartalan magmintavételt biztosító fúrást mélyítettünk (Sümegi Pál, Csökmei Bálint, Molnár Sándor, Persaits Gergő, Sümegi Balázs) a befagyott tó déli részének felszínéből, Dr. Kasza Ferenc környezetvédő szakember segítségével ${ }^{1}$. Tanulva a 2001-ben elkövetett hibákból teljes keresztszelvényt alakítottunk ki a tó déli medencéjében (2. ábra). Kihasználva a fagyott tőzegfelszín adta lehetőségeket a fúrások egy részét a láp centrumában mélyíthettük le (SüMEGI, 2007). A láp centrumában méteres tőzeg kifejlődéseket sikerült feltárnunk jelentős makrobotanikai anyaggal és pollentartalommal. A láp centrumában mélyített és feldolgozott fúrások egyikét mutatjuk be ebben a dolgozatban (2. ábra).

\section{A terület földtani, éghajlattani és növényzeti jellemzése}

A Baláta-tó a Belső-Somogyban található Szenta község és Kaszó-puszta között, a Szentai-erdöben. A Belső-Somogy egy pleisztocén alluviális hordalékkúp, amelynek felszínét mészben szegény futóhomok borított a jégkor végén. A homokbuckák közötti szélfútta mélyedésekben, amelyekbe a felszínt leöblítő csepperózió és bemosódás nyomán jelentős mennyiségű agyag halmozódott fel, lefolyástalan, pangóvizü, talaj- és esővíz táplálta tavak, lápfoltok alakultak ki. Ezek közül a Baláta-tó az egyik legnagyobb.

A futóhomok felszínek mélyebb részeiben kialakult vízzáró rétegek kialakulása mellett a lápok kialakulása szempontjából igen fontos földtani vonása a Belső-Somogynak, hogy a környező területekhez (Zalai-dombság Külső-Somogy, Marcali-hát) képest relatíve mélyebb fekvésű helyzetben található. Így a felszíni vizek és a talajvíz a belső-somogyi hordalékkúp irányába áramlanak. Ezt a hidrológiai helyzetet erősíti, hogy a dél-dunántúli völgyi vízválasztótól délre, a meridionális völgyekben kialakult patakok futásirányában helyezkedik el a vizsgált terület. Ezen tényezők hatására rossz lefolyású, magas talajvízállású, pangóvizes területek, valamint soligén és topogén víz táplálta kisebb tavak és lápszemek, összesen mintegy 1200 kisebbnagyobb tó található a területen. A földtani adottságok viszont csak az egyik részét alkotják a lápok, tavak köztük a Baláta-tó képződési feltételeinek, a klimatikus elemei legalább olyan fontosak (4. ábra).

1 Hálás köszönetünket fejezzük ki ezúton is Dr. Kasza Ferencnek az önzetlen és sokirányú terepi segítségért, amely nélkül nem érhettük volna el a dolgozatban bemutatott eredményeket. 


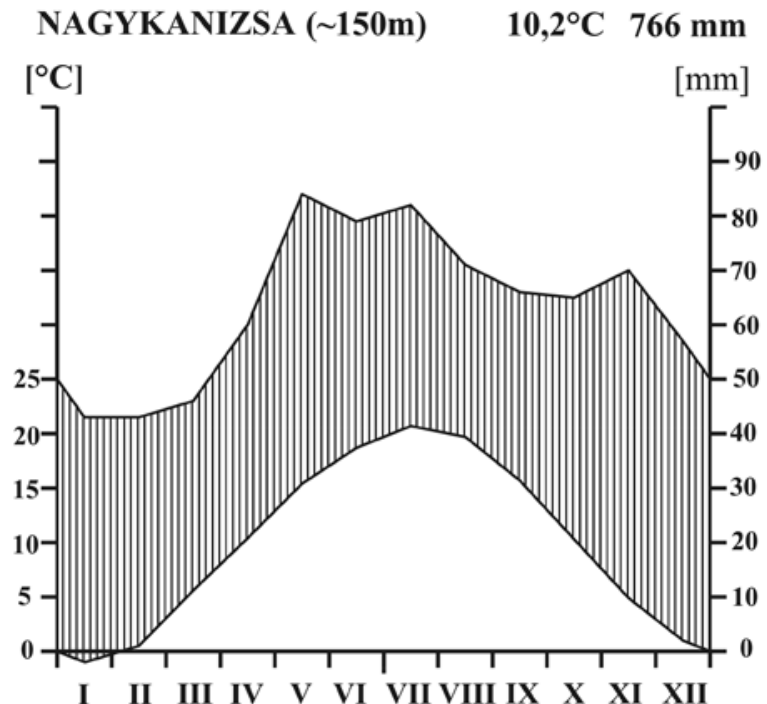

4. ábra: Nagykanizsa Walther - Lieth diagramja (Sümegi, 2009).

Fig.4.: Walther - Lieth climate diagram of the Baláta lake based on the last 150 years weather data from weather station at Nagykanizsa.

Belső-Somogy klímája erősen szubmediterrán hatás alatt áll. Ez hatás a legerőteljesebben a terület délnyugati részén a Dráva mentén fejlődött ki, ahol az évi csapadékbevétel 780-830 mm közötti, de az egész térségben kifejlődik a második őszi csapadék maximum is, a szubmediterrán éghajlati hatás egyik jellegzetes vonása (5. ábra). Bár a vizsgált területhez legközelebb a somogyszobi meteorológiai állomás helyezkedik el, de a nagykanizsai nyilvános, internetről is letölthető adatsorait használtuk fel a vizsgált régió éghajlati jellegzetességeinek bemutatására.

A nagykanizsai (hosszabb időszakot átfogó) adatsorával szemben $(766 \mathrm{~mm})$ a somogyszobi meteorológiai állomás adatai szerint a Baláta-tavat $712 \mathrm{~mm}$ évi csapadékbevétel jellemzi (KASZA-MARIAN, 2001). A nagykanizsai állomás adatai alapján a területet egyenletes eloszlású csapadékbevétel jellemzi (5. ábra), kettős, nyári és őszi csapadékmaximummal. A csapadékbevétel minden hónapban olyan jelentős a Baláta-tó környékén, hogy meghaladja a párolgás - párologtatás nyomán távozó vízmennyiséget, így a vízbevétele a területnek pozitív a több évtizedes átlagban a viszonylag magas évi középhőmérséklet $\left(9,8^{\circ} \mathrm{C}\right)$ ellenére is. A geológiai, hidrogeológiai és geomorfológiai adottságok mellett ez a pozitív vízmérleg játszik szerepet a jelentős számú tavi, lápi és mocsári terület, közte a Baláta tavi rendszer kialakulásáért a Belső-Somogyban.

Csapadékeloszlás szempontjából, a jelentős csapadékbevétel ellenére, a terület klímája átmeneti jellegü. Szubmediterrán típusú évek 70\%-ban, míg kontinentális jellegüek 30\%-ban jelentkeznek. Ez tehát azt jelenti, hogy durván minden harmadik év kontinentális jellegü. Ezekben az években a csapadékbevétel csökken és a nyári felmelegedés erőteljesebb, a nyári és téli hónapok közötti
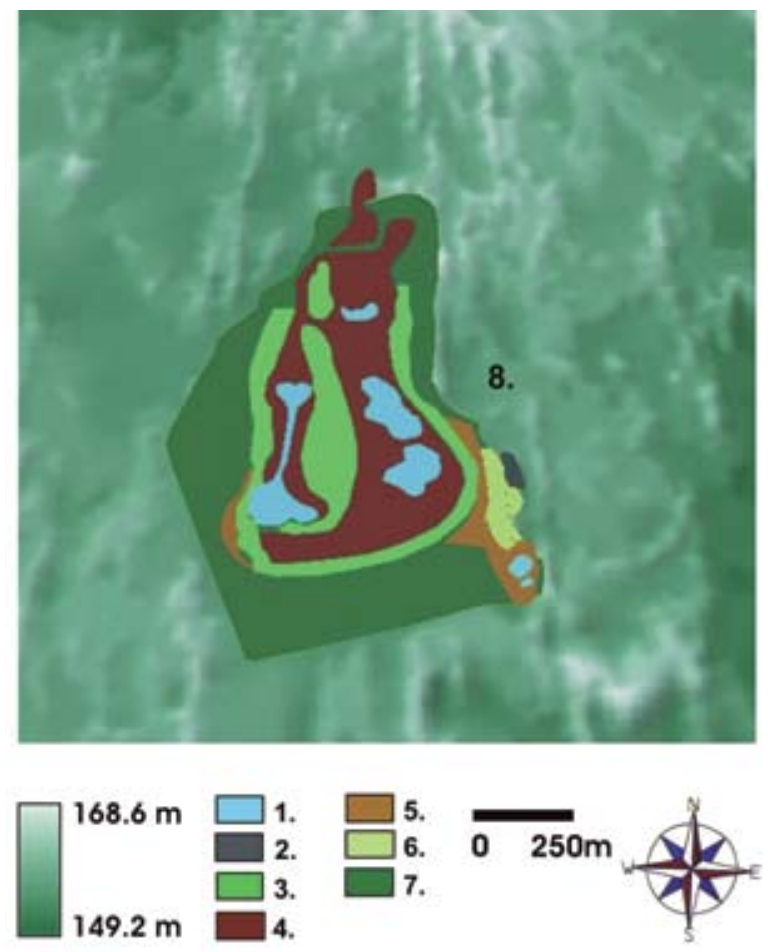

5. ábra: A terület vegetációs és földtani térképe (Persaits, 2009) 1. nyílt víz, 2. fenyves, 3. füzláp, 4. mocsár, 5. láprét, 6. rét, 7. égeres, 8.gyertyános-tölgyes.

Fig.5.: Vegetation and geological map of the Balata lake 1: open water surface, 2: populated pine-grove, 3: willow swamp (Calamagrosti - Salicetum cinereae), 4: marshland, 5: peatland , 6: meadow, 7: black alder bog forest (Dryopteridi-Alnetum typicum), 8: the oakhornbeam forests (Fraxino pannonicae-Carpinetum).

hőmérsékleti különbségek jelentősebbé válnak, az évi hőingás erőteljesebb lesz, a vízbevétel lecsökken.

A pozitív vízmérleg hatására a terület magasabb részei erdővel borítottak és a termelő gazdálkodás kialakulása előtt a magasabb talajvízállású területeket leszámítva zárt erdőtakaró borította vizsgált régiót. Az erdőkkel borított homokdünék között fekvő és deflációs laposban kialakult lápterület híres gazdag állat- és növényvilágáról. A tó egyik legnagyobb nevezetessége az Aldrovanda vesiculosa, de más növényritkaságok is találhatók: Comarum palustre, Sparganium minimum, Ludwigia palustris, Menyanthes trifoliata és Caldesia parnassifolia.

A lápon meglehetősen ritka és kicsi a nyílt vízfelület, ugyanis a tómedence jelentős részét ingólápok (Glycerietum maximae, Scirpo - Phragmitetum, Thelypteridi - Typhetum augustifoliae), fúzlápok (Calamagrostio - Salicetum cinereae) és zsombékosok (Caricetum elatae) és különböző hínártársulások (Spirodelo - Aldrovandetum, Nymphaeetum albo luteae) borítják. A tavat égeres láperdők és tölgy - szil - kőris ligetek zárják körül. A környező homokbuckákon pedig cseres - tölgyesek, az üdébb részeken pedig gyertyános - tölgyesek találhatók (5. ábra). 


\section{Vizsgálati módszerek}

Környezettörténeti vizsgálatokhoz zavartalan magmintavételre volt szükségünk, így a fúrást a nemzetközileg is elfogadott és a gyakorlatban is bevált eszközzel, az ún. módosított $5 \mathrm{~cm}$ átmérőjü Orosz-fúrófejjel végeztük el. A fúrómagokat még terepi körülmények között két réteg fóliába majd ezt követően alufóliába csomagoljuk. A fúrás mélységét és irányát még a helyszínen rögzítettük. A minták tárolása $4^{\circ} \mathrm{C}$-on hütőládában történt.

Az üledékfácies leírása során a Troels-Smith-féle (TROELS-SMITH, 1955) nemzetközi laza üledéktani kifejezéseket és szimbólumrendszert használtuk. A szemcseösszetételi meghatározás pedig a Magyarországon leginkább elterjedt Casagrande által kidolgozott (CASAgRANDE, 1947), hazánkban Papfalvi hidrométeres eljárásnak nevezett módszer segítségével történt (Vendel, 1957).

A zavartalan magfúrással kialakított szelvény kronológiai elemzését $5 \mathrm{db}$ radiokarbon vizsgálatra alapoztuk. Minden radiokarbon vizsgálathoz szenesedett apró nádtőzeget emeltünk ki a fúrásszelvényből a makromaradványok vizsgálata során. Valamennyi mintát a poznani Radiokarbon Laboratóriumban elemezték meg AMS módszerrel. A régészeti rétegtannal és adatokkal történő párhuzamosításhoz a mért BP (Before Present) adatokat Oxcal v.3.9. elnevezésű kalibrációs programmal (BRONK RAMSEY, 2001) számítottuk át a Krisztus előtti ( $B C=$ Before Christ) és Krisztus utáni ( $A D=$ After Day) évszámokra. $A$ radiokarbon adatok nyomán készített mélység-kor átszámítási modellt Bennett (1994) és Valanus (2008) munkái nyomán állítottuk fel.

A szerves anyag- és a karbonát-tartalom meghatározását a fúrásmag teljes hosszában $4 \mathrm{~cm}$-es osztásközzel végeztük el. Ennek meghatározása a Dean-féle izzításos tömegvesztésen alapuló eljárással történik (DEAN, 1971). Geokémiai vizsgálataink során az üledékben felhalmozódott elemek közül, 8 elem koncentrációját mértük meg, ezek: $\mathrm{Fe}, \mathrm{Na}, \mathrm{K}, \mathrm{Ca}, \mathrm{Zn}, \mathrm{Mg}, \mathrm{Mn}$, és a $\mathrm{Cu}$. Az elemzések a minták desztillált vizes oldatából készültek (DANIEL, 2004). A mintavétel során semmilyen fémeszközt nem használtunk és a mintavételezés helyét kémiailag semleges anyaggal töltöttük ki.

A negyedkori üledékrétegekben a legnagyobb mennyiségben előforduló mikrofossziliák a virágporszemek (pollenek). Vizsgálatuk a múlt századra nyúlik vissza, és annak ellenére is fontos információkat tudhatunk meg belölük, hogy a pollenanalitikai eredmények és az egykori vegetáció között nincs olyan szoros kapcsolat, mint a makrobotanikai anyag és az egykori növényzet között. A pollenmintákat BERGLUND - RALSKAJASIEWICZOWA (1986) módszere szerint dolgoztuk fel, hogy kinyerjük a pollentartalmat. A folyamat megkezdése előtt pedig STOCKMARR (1971) módszere szerint a mintákhoz külső forrásból származó, pontosan meghatározott mennyiségű Lycopodium - spórát adtunk, hogy a munkafolyamatok során bekövetkező pollenveszteség ismert arányban történjen. MAHER (1972) módszerének megfelelően minimum $300 \mathrm{db}$ pollent számoltunk meg taxononként, így biztosítva az adott taxon pollenkoncentrációjának adott mintára történő statisztikailag biztonságosnak tekinthető meghatározását.

A szelvény feldolgozása során jelentős számú makroszkópikus növényi maradvány, magvak, termések, szárak, levéltöredékek, szenesült fák, mohák, szövetmaradványok kerülnek elő. A vizsgálatok során a QLCMA (BARBER et al., 1994) módszer módosított változatát használtuk (JAKAB et al., 2004). A lágy növényi szövetek határozásához JAKAB - SüMEGI (2004, 2005) határozóját használták. A fúrásmagokból 5 cm-enként $3 \mathrm{~cm}^{3}$-es mintákat vettünk, majd a mintát $300 \mu$ m lyukátmérőjű szitán szürtük le. A koncentrációk meghatározása úgy történt, hogy ismert mennyiségü jelzőanyag $(0,5 \mathrm{~g}$ mákmag $=960+/-3 \mathrm{db})$ hozzáadása után Petri csészében $10 \mathrm{db} 10 \times 10 \mathrm{~mm}$-es kvadrátban megszámoltuk az összes mákmagot és maradványt sztereomikroszkóp segítségével. Az eredmények megjelenítésére a PSIMPOLL (BENNETT, 1992) programcsomagot használtuk. A tőzegszövet alkotók menynyiségét $1 \mathrm{~cm}^{3}$-re vonatkoztatva adjuk meg, a magvak mennyiségét pedig $3 \mathrm{~cm}^{3}$-re.

\section{Eredmények}

\section{Geomorfológiai vizsgálat eredménye}

A Baláta-tó egy alluviális hordalékkúp felszínén létrejött futóhomok területen (MAROSı, 1970) fejlödött ki (1. és 2. ábra). A futóhomok formák kifejlődése azt sugallja, hogy több futóhomok mozgási periódus is kialakult a kiszáradt hordalékkúp felszínén. A tó északi és nyugati részén párhuzamos, az egykori futóhomok felszínt visszatükröző maradványgerinc sorozatok alakultak ki, amelyek így több egymással párhuzamos kifúvásos mélyedéseket, szélbarázdákat fognak közre. Maga a tó három posztgenetikusan roncsolt szélbarázda találkozási pontjánál, a szélbarázdák peremén fennmaradt maradékgerinceket részben elroncsoló lokális kifúvási mezőben fejlődött ki. Ugyanakkor a szélbarázdák nem teljesen roncsolódtak el, a tó déli végén világosan felismerhetők az északi végén látható szélbarázdák folytatása (2. ábra).

A tavi rendszer tehát részben a szél által csatornaszerüen erodált szélbarázdákat tölti ki, másrészt a szélbarázdák találkozási pontjánál, a mai Baláta-tó déli részén található szél lyukat, így a tó nem egy egységes vízfelületet alkot, hanem párhuzamosan, hoszszan elnyúló, mélyebb és sekélyebb részekből áll ( 2 . és 5 . ábra). A fekü homok kőzet így különböző magasságban fejlődhetett ki és a legegységesebb vízfelület a tó déli részén alakulhatott ki, de a tó vízmélysége mindig csekély lehetett, a legmélyebb pontokon alig haladhatta meg a 2 métert, maximum 3 méter lehetett, mert a szélerózió igen kismértékű volt a hidrogeológiai helyzet, a relatíve magas talajvíztükör szint következtében. A kisebb mértékű szélerózió nyomán az üledékgyűjtő rendszer is sekély mélységű lett.

A bonyolult felépítésü, változatos geomorfológiával, lokális talajvíz feláramlással (talajvízforrással) jellemezhető üledékgyűjtő medence rendszerben igen változa- 
tos vízborítás alakulhatott ki, különösen, ha figyelembe vesszük a csapadékmennyiségtöl, párolgástól és párologtatástól függő talajvíz utánpótlás ciklikus változásait és a tó vízszintjének a változásait. Mivel az üledékgyűjtő rendszer sekély mélységű volt, így a részmedencék teljes kiszáradása és a 2-3 méter körüli vízborítása között változhatott tavi rendszer a Baláta tavon. Az üledékgyűjtő rendszer morfológiai vizsgálata egyértelműen alátámasztotta azt a döntésünket, hogy a Baláta-tó déli részét vizsgáljuk meg, mert a geomorfológiai helyzet alapján itt ezen a területen alakulhatott ki jelentősebb mértékű és többé-kevésbé folyamatos vízborítás.

\section{Radiokarbon vizsgálat eredményei}

Az AMS vizsgálatok alapján (1. táblázat) szubatlantikus kort, a magyarországi archeosztratigráfiai besorolás alapján (VADAY, 2004) a vaskortól a középkor végéig tartó időhorizontot fogja át. Az ülepedési ráta változása igen jellegzetes volt a szelvényben a vaskor kezdetén mintegy $0.6-0.2 \mathrm{~mm} / \mathrm{e} v$ ülepedési sebesség jelentkezett (6. ábra), amely megfelel a magyarországi holocén korú, eutróf - mezotróf tavak ülepedési rátájának (SüMEGI, 2003). A kalibrációs során mind az 1950-től értendő cal BP, mind a Krisztus születésétől számított cal BC/AD éveket kiszámoltuk a Reimer et al. 2013 Calib Rev. 7.0.0. programmal. megakadályozta az üledék lerakódását. De felmerülhet természetes, vagy mesterséges tőzegtűz kialakulásának és posztgenetikus réteg megsemmisülésnek, réteghiánynak a lehetősége is. A legvalószínűbb oka az üledékképződés lelassulásának, hogy a lápos tó vízszintje lecsökkent a Krisztus elötti I. és a Krisztus utáni III. századok között, és zárt növényzet borította el a tómedrek partját, az erózió és üledékakkumuláció ennek nyomán lassulhatott le és az eutróf tavi rendszer fokozatosan aktív tőzegképző, lápos környezetté alakulhatott. A tőzegképző környezet kialakulását követően az ülepedési ráta ismét megnövekedett.

A radiokarbon vizsgálatok alapján a vizsgált terület szerves anyagban dús képződményei a holocén végén, a vaskortól halmozódtak fel, így a homokfekü felett kialakult, egyértelmüen a pleisztocén végén, tavi környezetben lerakódott minerorganikus, kőzetlisztben gazdag rétegek és a késő-holocén rétegek között minimum 7000-8000 éves réteghiány is kialakulhatott. A geológiai eredmények alapján a pleisztocén végétől a szubboreális kronozónáig, a vaskor kezdetéig üledék nem halmozódott fel a területen. Ennek oka egyértelmüen az, hogy nem alakult ki vízborítás a területen a jégkor végétől a vaskor kezdetéig.

\begin{tabular}{|c|c|c|c|c|c|}
\hline $\begin{array}{c}\text { Mélység } \\
(\mathrm{cm})\end{array}$ & Minta & UNCAL BP évek & CAL BC/AD évek $(2 \sigma)$ & $\begin{array}{c}\text { CAL BP évek } \\
(2 \sigma)\end{array}$ & Labor kód \\
\hline $21-25$ & nád & $375+/-30$ & $1446-1632 \mathrm{AD}$ & $318-504$ & Poz-7989 \\
\hline $41-45$ & nád & $645+/-30$ & $1282-1395 \mathrm{AD}$ & $555-668$ & Poz-8071 \\
\hline $61-65$ & nád & $995+/-30$ & $987-1151 \mathrm{AD}$ & $799-963$ & Poz-7988 \\
\hline $81-85$ & nád & $2140+/-30$ & $353-56 \mathrm{BC}$ & $2005-2302$ & Poz-8092 \\
\hline $101-105$ & nád & $2425+/-30$ & $749-404 \mathrm{BC}$ & $2353-2698$ & Poz-7991 \\
\hline
\end{tabular}

1. táblázat: $A$ Baláta-tavi I. fúrás mintáin végzett radiokarbon (AMS) vizsgálat eredményei (radiokarbon adatok kalibrációja Reimer et al. 2013 Calib 7.0.0. program nyomán).

Table 1.: Radiocarbon ages of the core profile of Lake Baláta

(C-14 calibration based on Reimer et al. 2013 Calib 7.0.0. programme).

Az ülepedési ráta viszont igen erőteljesen megemelkedett, mintegy megduplázódott $(0.7-1.0 \mathrm{~mm} /$ év) a szerves anyagban dús tavi réteg és tőzegképződés határán. Ez nem véletlen, mert az úszóláp képződés során felgyorsul az üledék képződése (SüMEGI, 2003) a makrofita vegetáció vertikális és horizontális gyors növekedése (BALOGH, 1983, 2000) következtében és az eredetileg sekély tavi környezet viszonylag gyorsan elláposodik (BRAun et al., 1993).

Viszont viszonylag jelentős időkülönbség (11001500 naptári év) mutatható ki a tavi rétegek és a tőzeg réteg között. Ennek oka több dolog is lehet, egyrészt felmerült, hogy ezt a medencét is átalakították, tisztították a késő-vaskorban, a császárkorban, mint azt már több kárpát-medencei üledékgyűjtő medencénél korábban kimutattuk (SüMEGI, 1998, 1999, 2004), vagy az úszóláp kialakulása, fejlődése, mozgása megszürte a medence vizét (BALOGH, 1983; BrAun et al. 1993) és

\section{Üledékföldtani vizsgálat eredményei}

A Troels - Smith üledékkategorizálási rendszer segítségével a szelvényen belül 9 üledékes zónát lehetett makroszkóposan elkülöníteni, amelyeket az alábbi táblázat tartalmazza (2. táblázat). A vizsgált fúrásunk mellett még 17 fúrást vizsgáltunk meg szedimentológiai - üledékföldtani szempontból. A bemutatásra kerülő fúrás tartalmazta a legteljesebb rétegsort, a többi fúrásponton vékonyabb üledékréteg kifejlődést lehetett megfigyelni és a makrofosszíliák szempontjából legfontosabb szerves anyagban gazdag rétegek is gyengébben fejlettek voltak.

A vizsgált fúrásunk mellett még 17 fúrást vizsgáltunk meg szedimentológiai - üledékföldtani szempontból. A bemutatásra kerülő fúrás tartalmazta a legteljesebb rétegsort, a többi fúrásponton jóval vékonyabb üledékréteg kifejlödést lehetett megfigyelni és a makrofosszíliák szempontjából legfontosabb szer- 


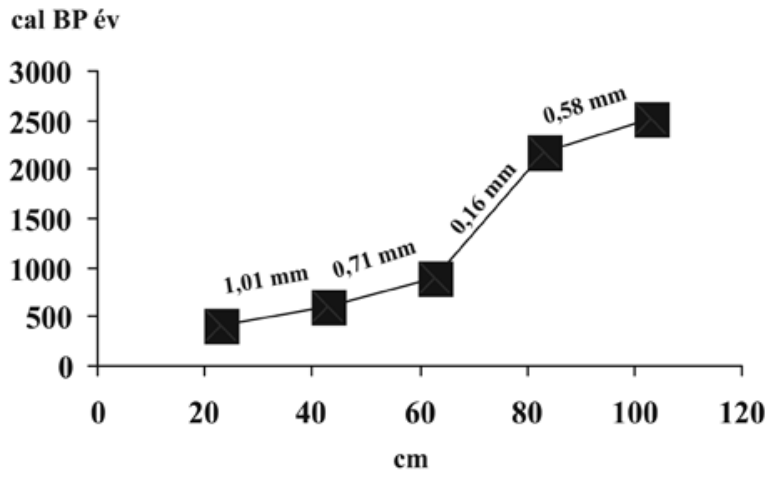

6. ábra: A késő-holocén folyamán a Baláta-tó déli medencéjében kialakult ülepedési ráta (Sümegi, 2009)

Fig.6.: Late Holocene sedimentation rate of the analysed core sequence from the Baláta lake (Sümegi, 2009)

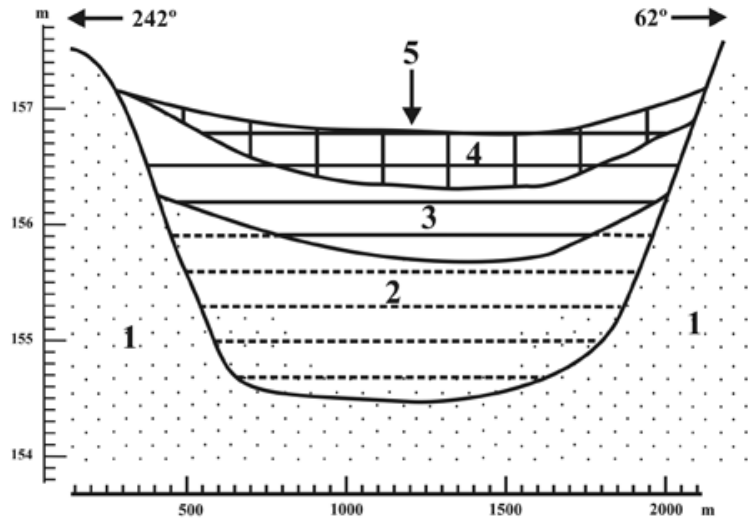

7. ábra: A Baláta-tó déli medencéjének földtani keresztszelvénye (Sümegi, 2009)

Fig.7.: Physical characteristics and elemental concentrations from the Baláta lake sediment plotted against depth (Sümegi, 2009)

\begin{tabular}{|c|c|c|}
\hline $\begin{array}{c}\text { Mélység } \\
(\mathbf{c m})\end{array}$ & Troel-Smith kategóriák & Rétegtani leírás \\
\hline $0-40$ & Th4 & Világosbarna nyers tőzeg. \\
\hline $40-45$ & As2 Sh2 & Feketésbarna tavi iszap. \\
\hline $45-70$ & Th2 Tb2 & Barnágosbarna nyers tőzeg. \\
\hline $70-100$ & As3 Th1 & Sárgásbarna holocén tavi üledék. \\
\hline $100-108$ & As3 Sh1 & Szürkészöld színü jégkori tavi - mocsári üledék. \\
\hline $108-140$ & Ag2 As2 & Szürkészöld színű jégkori tavi üledék. \\
\hline $140-240$ & Ag3 As1 & Sárgásszürke színü jégkori futóhomok réteg. \\
\hline $240-250$ & Ga4 & Zöldesszürke színű jégkori tavi üledék. \\
\hline $250-260$ & Ag3 Ga1 & \\
\hline
\end{tabular}

2. táblázat: A Baláta-tóból kiemelt fúrásszelvény szedimentológiai leírása (Sümegi, 2007 nyomán). Table 2.: Sedimentological description of the core profile of Lake Baláta (after Sümegi, 2007).

ves anyagban gazdag rétegek is gyengébben fejlettek voltak. A fúrások nyomán kialakított keresztszelvény alapján (7. ábra) is ez a fúrásszelvény tartalmazta a legteljesebb rétegkifejlődést.

A 2,6 méteres szelvényen $4 \mathrm{~cm}$-ként végzetünk szerves anyag, karbonát tartalom vizsgálatot és vízoldható főelem összetétel meghatározást, így a szelvényben $85 \mathrm{db}$ mintát elemeztünk meg (7. ábra).

A geokémiai vizsgálatok alapján hét megközelítőleg azonos geokémiai környezetben kialakult zónát (BGK) lehetett a szelvényben elkülöníteni (8. ábra).

\section{BGK-1 (250-260 cm)}

Az első geokémiai zóna 260 és 252 cm között húzódik, szervetlen anyag (90-95 \%) igen jelentős dominanciája jellemzi ezt a szintet, ugyanakkor karbonátot is ki lehetett mutat ebben a geokémiai horizontban. A kar- bonát a vízoldható Ca jelentős mennyisége alapján (8. ábra) egy korábbi alacsony vízállású szakaszban a fedőrétegek irányából oldódhatott a fekü felé. A homokos kőzetliszt rétegben kimutatható jelentős mennyiségü vízoldható föelem alapján a Baláta-tó medencéjében, valószínűleg még a jégkor végén jelentős vízszint fluktuációk játszódhattak le.

BGK-2 (240-250 cm)

A második zónát 240-250 cm között húzódó futóhomok réteg alkotja, jelentős karbonát tartalommal. A karbonát homokfrakcióban található ásványi kalcit jelenlétéhez kötődik, a melynek vízoldható része igen csekély (8. ábra) kötődik. A futóhomok képződés a fedőréteg alapján egyértelmüen jégkori és a karbonát jelenléte azt mutatja, hogy a Belső-Somogyi területen nem csak karbonátmentes futóhomok halmozódott fel. 


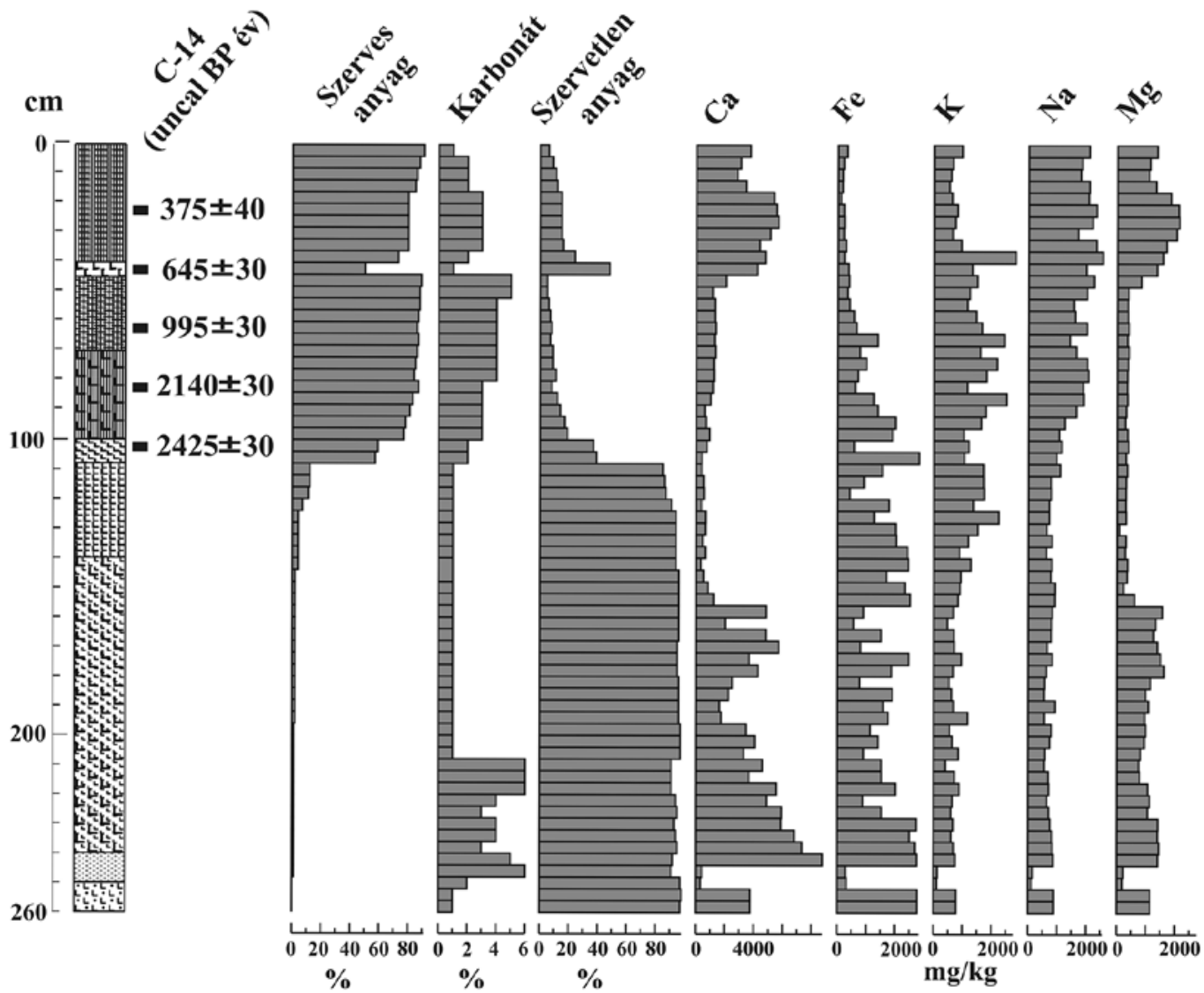

8. ábra: A Baláta-tavi III. fúrásszelvény vízoldható elemtartalmának változása (Nátyi-Majkut-Sümegi, 2009).

Fig. 8.: The results of geochemical analysis of the core III. from Lake Baláta (Nátyi-Majkut-Sümegi, 2009).

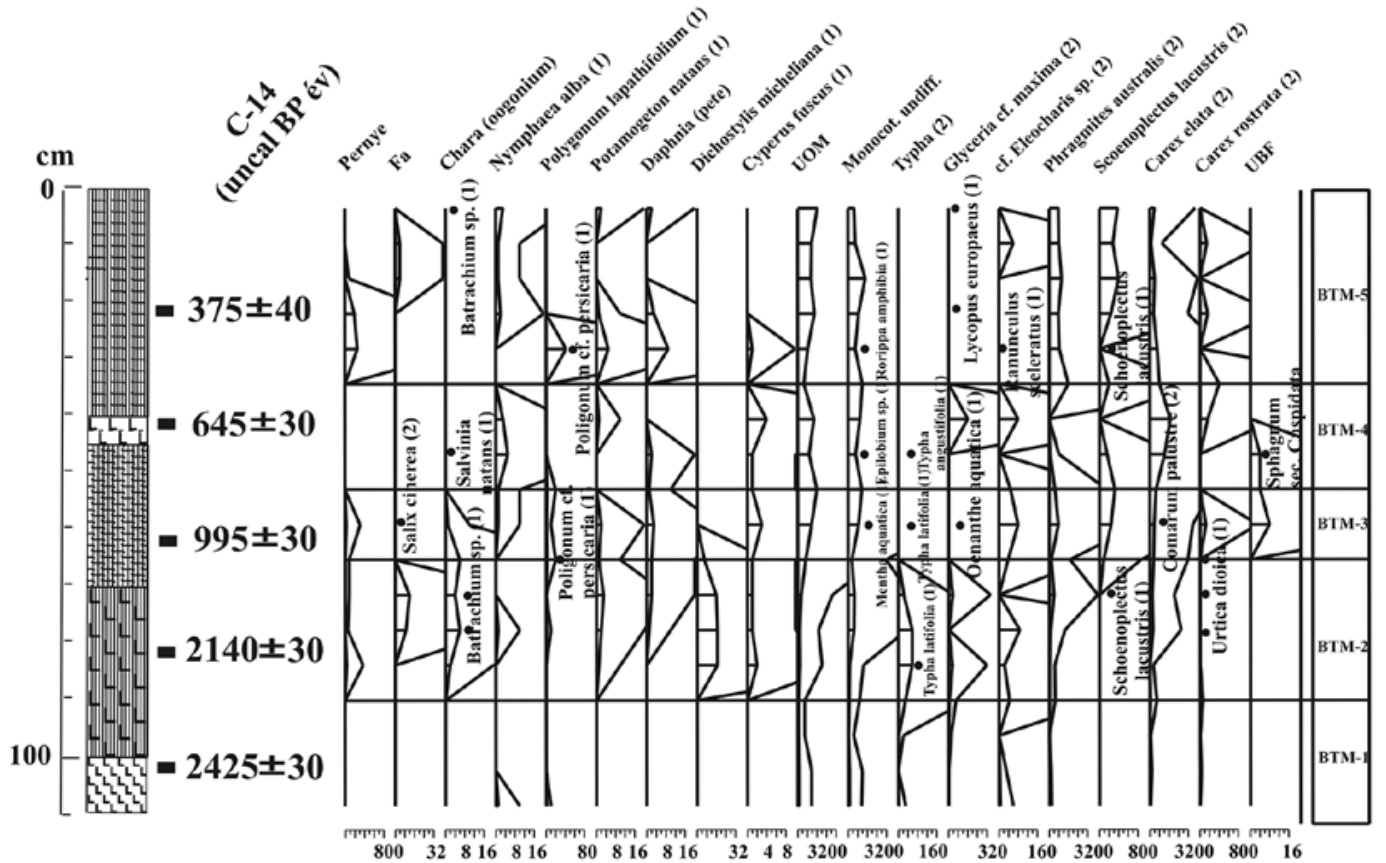

9. ábra: A Baláta-tavi III. fúrásszelvény makrobotanikai anyagának változásai (Jakab, 2007).

Fig. 9.: Macrobotanical remains and data change from the analysed core sequence of the Baláta lake (Jakab, 2007). 
BGK-3 (210-240 cm)

A harmadik geokémiai-üledékföldtani zónát karbonátos, szerves anyagtól mentes agyagos kőzetliszt réteg alkotja. Az üledék egyértelműen tavi, hidegvízű, oligotróf környezetben halmozódott fel és rendkívül hasonló a Kárpát-medence más területein a jégkor végén felhalmozódott minerorganikus feltöltődésü tavak üledékeihez (Sümegi et al. 1999, Sümegi, 1996, 2004). Ugyanakkor jelentős a vízoldható karbonáttartalma is az üledéknek

\section{BGK-4 (150-210 cm)}

A negyedik geokémiai-üledékföldtani zónát alacsony karbonáttartalom és szerves anyagtól mentes agyagos kőzetliszt réteg alkotja. Az üledék kifejlődése az előző geokémiai-üledékföldtani zónához hasonló, de itt nem alakult ki karbonátos horizont, valamint ennek a szintnek a vízoldhat vas és kálium tartalma is jelentősebb, mint az előző horizontnak. Az üledékes összlet egyértelműen tavi, hidegvízü, oligotróf környezetben halmozódott fel és rendkívül hasonló a Kárpát-medence más területein a jégkor végén felhalmozódott minerorganikus feltöltődésű tavak, mocsarak üledékeihez (Sümegi et al. 1999, Sümegi, 1996, 2004, 2007). A minerorganikus feltöltődés befejező, mocsári jellegű szakaszához hasonlítható a $\mathrm{Fe}, \mathrm{K}$ tartalom változásai alapján.

BGK-5 (110-150 cm)

Az ötödik geokémiai-üledékföldtani zónát növekvő szerves anyag, vízoldható $\mathrm{K}, \mathrm{Na}$ tartalmú mentes agyagos kőzetliszt réteg alkotja. Az üledék kifejlődése az előző geokémiai-üledékföldtani zónához hasonló, de a szerves anyag, a $\mathrm{K}$ és $\mathrm{Na}$ tartalom növekedése alapján az üledékgyűjtő medence környezetében már megindult a talajképződés és a felszínen lévő jégkorban felhalmozódott szilikátos üledék mállása. Ez az üledékes horizont leginkább a jégkor végén, a holocén kezdetén a tavi - mocsári üledékgyüjtő rendszerekben felhalmozódott üledékes rétegekkel párhuzamosítható (Sümegi et al. 1999, Sümegi, 1996, 2004).
BGK-6 (110-60 cm)

A hatodik geokémiai üledékföldtani zónában a szerves anyag tartalom ugrásszerüen megemelkedett és jelentős szerves anyag tartalmú eutróf tavi üledék halmozódott fel. Az üledék karbonát, vízoldható vas, magnézium és nátrium tartalma jelentős. A tavi környezet a tőzeg foltok alapján már ebben a horizontban láposodhatott és úszóláp foltokkal tagolt eutróf tavi környezet fejlődhetett ki a radiokarbon adatok alapján a vaskor folyamán.

\section{BGK-7 (60 cm-től a felszínig)}

A hetedik geokémiai üledékföldtani zónában a szerves anyag tartalom - egyetlen horizontot leszámítva (41-45 cm között) - végig jelentős marad és ebben a horizontban zárt tőzegréteg halmozódott fel. 41-45 cm között egy égett horizont fejlődött ki, az átégett tőzeg fekete hamu és koromrétegként helyezkedett el a tözegbe. A radiokarbon vizsgálat alapján a XIII. századdal párhuzamosítható ennek a szintnek a kialakulása.

Kifejlődése a XIII. századi rendkívüli szárazsághoz, a forró és száraz nyarak kifejlődéséhez köthető (Sümegi et al. 2009), de nem zárható ki a láp tudatos égetése sem, bár ehhez is jelentős száraz periódus kialakulása szükséges. Az égett réteg káliumcsúcsát leszámítva kalcium, nátrium, magnézium dús tőzegréteg fejlődött ki a vizsgált területen egy láposodott tó felszínén. Az elemösszetétel alapján hínár, nád, gyékény és sás növények egyaránt tőzegalkotó mennyiségben voltak jelen az üledékgyüjtő medencében.

\section{Makrobotanika}

A makrofosszília vizsgálatokat Jakab-Sümegi (2007) korábban már publikálták. Az eredmények alapján az üledékoszlopot 5 zónára osztottuk fel, BTM-1, BTM-2, BTM-3, BTM-4, BTM-5 elnevezést adva az egyes zónáknak (4. táblázat).

Makrobotanikai anyag csak $105 \mathrm{~cm}$-től a felszín felé fordult elő (10. ábra). A zónák makrobotanikai öszszetétele a következő volt:

\begin{tabular}{|c|c|c|}
\hline $\begin{array}{c}\text { Mélység } \\
(\mathbf{c m})\end{array}$ & Geokémiai zóna & Geokémiai zóna jellemzői \\
\hline $0-60$ & BGK-7 & $\begin{array}{c}\text { Szerves anyag, Na -, Mg - tartalom maximumon, egy égett, K-gazdag } \\
\text { horizonttal. }\end{array}$ \\
\hline $60-110$ & BGK-6 & Szerves anyag, Na -, Mg - tartalom és ásványi kalcit a maximumon. \\
\hline $110-150$ & BGK-5 & Növekvo szerves anyag, karbonát, K - és Mg - tartalom. \\
\hline $150-210$ & BGK-4 & Jelentős szervetlen anyag, Fe -, Na - tartalom. \\
\hline $210-240$ & BGK-3 & $\begin{array}{c}\text { Maximális szervetlen anyag, szerves anyag nincs, jelentős vízoldható } \\
\text { Ca -, Mg - tartalom. }\end{array}$ \\
\hline $240-250$ & BGK-2 & Maximális szervetlen anyag, szerves anyag nincs, jelentős ásványi \\
\hline $250-260$ & BGK-1 & Maximális szervetlen anyag, minimális szerves anyag tartalom. \\
\hline
\end{tabular}

3. táblázat: A Baláta-tóból kiemelt fúrásszelvény vízoldható elemtartalma és geokémiai zónái.

Table 3.: Geochemical zones and water-soluble elements content of the core taken from Lake Baláta. 


\begin{tabular}{|c|c|c|}
\hline $\begin{array}{c}\text { Mélység } \\
(\mathbf{c m})\end{array}$ & $\begin{array}{c}\text { Makrobotanikai } \\
\text { zóna }\end{array}$ & Makrobotanikai zóna jellemzői \\
\hline $0-20$ & BTM-6 & Recens sás, nád és gyékénytörmelék. \\
\hline $20-45$ & BTM-5 & $\begin{array}{r}\text { Pernye maximum, tőzegégés, égés után gyors } \\
\text { vízszintemelkedés, nádas terjedés és záródás, zárt nád - } \\
\text { gyékény - harmatkásás láp kialakulása. }\end{array}$ \\
\hline $45-60$ & BTM-4 & $\begin{array}{c}\text { Nádas visszaesése, csökkenése, zsombéksás terjedése, } \\
\text { tőzegmoha megtelepedés, kiszáradó semlyék és láposodás. }\end{array}$ \\
\hline $60-70$ & BTM-3 & $\begin{array}{r}\text { Úszólápoka jellemző makrobotanikai anyag koncentrációja } \\
\text { kiemelkedő, nádas terjedésnek } \\
\text { indult, lombosmoha, tőzegeper megjelenése. }\end{array}$ \\
\hline $70-90$ & BTM-2 & $\begin{array}{c}\text { A makrofosszilia tartalom megemelkedett, Chara és iszaplakó } \\
\text { társulás a fenéken, nádas, gyékényes, harmatkásás vegetáció } \\
\text { kiterjedt. }\end{array}$ \\
\hline $90-105$ & BTM-1 & $\begin{array}{r}\text { Minimális makrobotanikai maradvány koncentráció, gyér } \\
\text { vegetációs boritású tavi állapot. }\end{array}$ \\
\hline
\end{tabular}

4. táblázat: A Baláta-tóból kiemelt fúrásszelvény makrobotanikai zónái (Jakab-Sümegi 2007 nyomán).

Table 4.: Macrobotanical zones of the analysed core sequence of Lake Baláta (after Jakab-Sümegi 2007).

BTM-1 $(105-90 \mathrm{~cm})$

A fúrás 105 és $90 \mathrm{~cm}$ között sárgás-barna, majd barnásszürke tavi üledéket tartalmazott, melyben nagyon alacsony volt a makrofosszília koncentráció is, ami minerogén üledékképződésre és alacsony vegetációra utal. A makrofosszília elemzés kimutatta közönséges nád (Phragmites australis), gyékény (Typha sp.), harmatkása (Glyceria cf. maxima), tündérrózsa (Nymphaea alba), (Polygonum lapathifolium), csetkáka (Eleocharis sp.) és zsombéksás (Carex elata) maradványok jelenlétét, gyakorlatilag minden olyan fajt amelyek a lápi vegetáció fontos összetevői lettek (10. ábra).

A makrobotanikai anyag koncentrációja nagyon alacsony volt, ami a gyér vegetációs borításra utal. A minták kora $101-105 \mathrm{~cm}$ között $2425 \pm 30{ }^{14} \mathrm{C}$ BP évnek (Krisztus előtti 700 és 400 évek közötti kora vaskornak) adódott. Így mivel az előző üledékes zóna egyértelműen még a jégkor végén alakulhatott ki az üledék felhalmozódása a mederben a körülbelül 70008000 éves üledékhiányt követően csak a szubboreális kronozóna végén, a szubatlantikus kezdetén indulhatott meg.

\section{BTM-2 (90-70 cm)}

$70 \mathrm{~cm}$-ig barnásszürke tavi iszap rakódott le. A növekvő makrofosszília koncentráció, a nád (Phragmites) és a zsombéksás (Carex elata) rizómák, valamint a vízibolha (Daphnia) peték növekvő száma a zónában megindult eutrofizáció fokozódására utal. A pollenelemzés a Phragmites elterjedését mutatja. A tó körül zárt mocsárzóna alakult ki, de a nyíltvíz felülete jelentősen felülmúlta a jelenkori állapotot is.

A hínárfajokat legnagyobb mennyiségben az úszó békaszőlő (Potamogeton natans) képviseli. A csillárkamoszat (Chara) jelenléte a víz relatív magas karbonáttartalmát jelzi. A békaboglár (Batrachium) a sekély és felmelegedő vízrészeket kedveli. A tündér- rózsa (Nymphaea alba) maradványokból viszonylag kevés került elő. A meder ugyanekkor rendszeresen kiszáradt, amire a lapulevelü keserüfü (Polygonum lapathifolium), csetkáka (Eleocharis), iszapkáka (Dichostylis micheliana) és a barna palka (Cyperus fuscus) együttes jelenléte utal.

Ebben a zónában jellemző a gyékény (Typha sp.) és a harmatkása (Glyceria cf. maxima) nagyobb menynyisége is. Ezek nyomán feltételezhetjük az úszólápok kialakulását is, bár az azokon legtöbb esetben megtalálható tőzegpáfrány (Thelypteris palustris) maradványai nem kerültek elő.

\section{BTM-3 (70-60 cm)}

Az üledék lényeges változáson ment keresztül mire elérte a $70 \mathrm{~cm}$-t: a barnásszürke tavi iszap világosbarna nyers tőzegbe megy át. A makrofosszília koncentráció lényegesen megnő ebben a zónában, ami a nyílt vízfelület csökkenésének a következménye.

A nyíltvíz kiterjedése nagyjából megegyezik a jelenkori állapottal. A terület déli részén a fúráspont körül megnő a nádasok kiterjedése. Ezzel párhuzamosan kimutathatóan megnövekszik a Phragmites pollenkoncentrációja is. A nádasokban a tavi káka (Schoenoplectus lacustris) gyarapodásnak indul. A lombosmoha maradványok megjelenése az üledékben a sekély felszíni víz kialakulására enged következtetni.

A Typha sp. és a Glyceria cf. maxima eltűnnek a fúráspont környékéről. A Daphnia sp. növekvő menynyiségének köszönhetően intenzív eutrofizáció indul meg. Emellett a Chara sp. csökkenő mennyiségéből a víz karbonáttartalmának csökkenésére következtethetünk. Az iszaplakó fajok közül a Dichostylis micheliana eltünik, helyét a Cyperus fuscus veszi át.

A hínárok között a Potamogeton natans még mindig gyakori, és a Nymphaea alba mennyisége is nő. Ebben a zónában jellemző még a baracklevelü keserüfü 


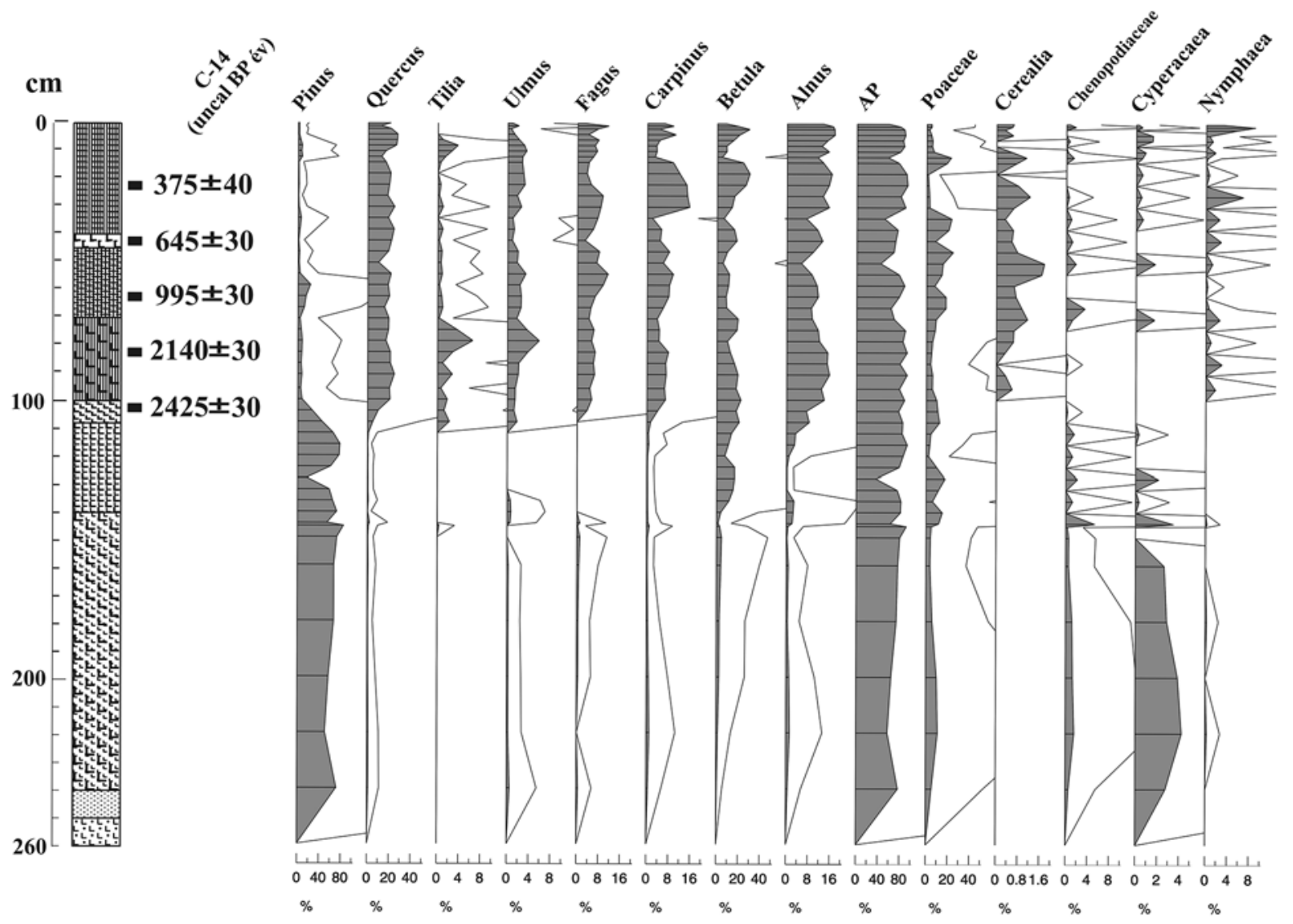

10. ábra: A Baláta-tavi III. fúrásszelvény pollen anyagának változásai (Töröcsik, 2007).

Fig.10.: Percentage pollen and spore diagram of selected taxa from the analysed core sequence of the Baláta lake in the last 3000 years (Töröcsik, 2007).

(Polygonum cf. persicaria), hamvas füz (Salix cinerea), vízi menta (Mentha aquatica), széleslevelü gyékény (Typha latifolia), mételykóró (Oenanthe aquatica) és a tőzegeper (Comarum palustre) maradványai is.

\section{BTM-4 (60-45 cm)}

A makrofosszília koncentráció a zónában többé-kevésbé változatlan csak a különböző fajok egymáshoz viszonyított aránya tolódik el. A Carex elata elterjedése és a Phragmites és Schoenoplectus hanyatlása a vízszint jelentős csökkenésére utal. Ez a szárazódás $50 \mathrm{~cm}$-nél (750 BP év) éri el tetőpontját, ahol a Phragmites és a Schoenoplectus el is tűnik a mintából. A Phragmites mennyisége a pollendiagramon is minimumot mutat ebben az időszakban.

A vízszint csökkenésére utal a Potamogeton natans és a Daphnia sp. alacsony mennyisége a mintában. A Pediastrum sp. alga csúcsa a pollendiagramon is sekély, felmelegedő, eutróf víz kialakulására utal. A Nymphaea alba gyarapodásnak indult a mélyedésekben a zsombékosok között. Megjelent a rucaöröm (Salvinia natans) is. A kiszáradó semlyékek iszapján nagy mennyiségben élt a Cyperus fuscus és a cf. Eleocharis is, valószínüleg a vízifü (Eleocharis acicularis). A Sphagnum sec. Cuspidata tőzegmoha előkerülése már a láposodást bizonyítja.
BTM-5 $(45-20 \mathrm{~cm})$

A világosbarna nyers tőzeg lerakódás folytatódik ebben a zónában. 40-45 cm között egy égetett szintet lehet megfigyelni kis mennyiségü feketésbarna tavi iszappal. $A z$ előző zóna alacsony vízszintjének lezárásaként a tó medrét kisebb tüz érintette, amire az elszenesedett Potamogeton natans és Polygonum lapathifolium magvak mellett a megnőtt pernyekoncentrációból következtethetünk. A tüz azonban csak kisebb intenzitású lehetett (a magvak csak elszenesedtek), és nem okozott réteghiányt, ami a radiokarbon adatokból is egyértelműen látszik.

Ezt követően a vízszint megemelkedett és a friss iszapot és tőzegfelszínt betelepítették a különféle iszaplakó szervezetek, úgymint; a Cyperus fuscus, Rorippa amphibia (vízi kányafü), Polygonum persicaria, Polygonum lapathifolium és Ranunculus sceleratus (torzsika boglárka). Az átmeneti sekély vízben sok Potamogeton natans és Daphnia sp. élt.

A kiégett felszínt ezután gyorsan visszafoglalta a nádas, és a BTM-3 zónához nagyon hasonló állapot alakul ki. A pollendiagramon is a Phragmites terjedését tapasztaljuk. A Phragmites mellett jelentős mennyiségben nőtt a Schoenoplectus lacustris és a Lycopus europaeus is. Az iszaplakó fajok hiányának következtében a nádasok egyre zártabbá váltak. 


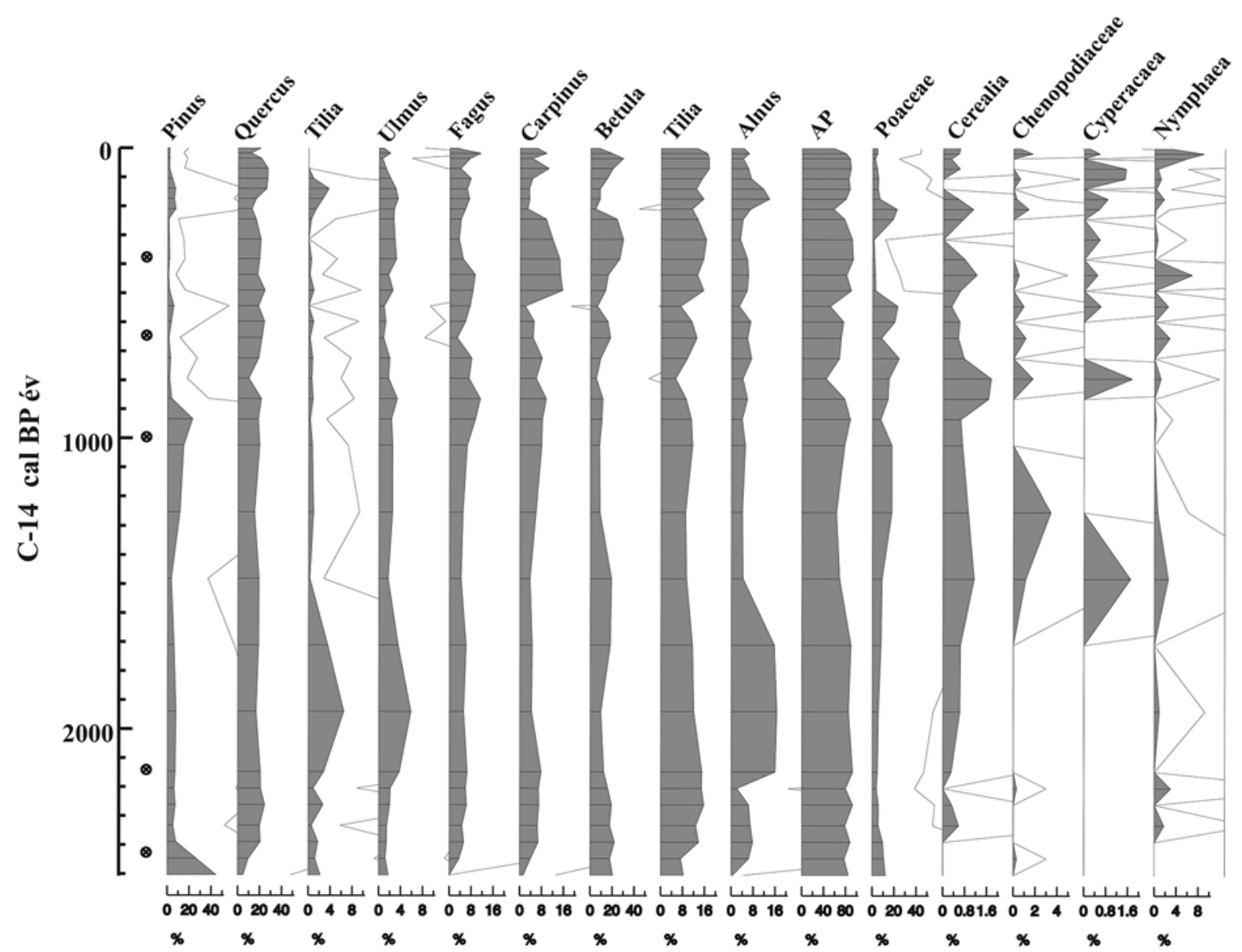

11. ábra: Az utolsó 3000 év pollen összetétel változásai Baláta-tavi III. fúrásszelvény mentén (Törőcsik, 2007). Fig.11.: Description of geochemical, molluscan and pollen zones within the Baláta lake sedimentary sequence (Töröcsik, 2007).

Ez az állapot lényegében megfelel a Baláta-tó déli részén, a fúráspont körül jelenleg megfigyelhető vegetációnak. Ez alapján a török kortól kezdődően a területen a nádas záródás, zárt nádláp kialakulása és a füzláp terjedése jellemzi a vizsgált területet.

BTM-6 $(0-20 \mathrm{~cm})$

Döntően recens nád-, gyékény-, füz-, káka-, és sásmaradványok.

\section{Pollenanalitikai vizsgálat eredménye}

A pollenvizsgálatot több lépésben végeztük el a területen, először JuHÁsz Imola (2007) végzett $16 \mathrm{~cm}$ ként pollenelemzéseket, majd egy palinológus team 4 cm-ként egymástól függetlenül megvizsgálták a rétegsor pollenösszetételét. Ez utóbbi eredményeit mutatjuk be (10. és 11. ábra).

A pollenvizsgálat során 69 pollentaxont lehetett kimutatni ezek közül a legfontosabb dominancia változásait mutatjuk be és a statisztikai elemzések nyomán készült pollenzónák (BTP) eredményeit az alábbiakban közöljük.
BAP-1 $(130-260 \mathrm{~cm})$

$\mathrm{Az}$ egyértelműen jégkori (pleisztocén végi) rétegekben a fásszárú növények mindenek előtt a fenyőfélék dominálnak (60-85 \%). Ez alapján az erdei fenyő egyértelműen erdőalkotó lehetett a vizsgált üledékgyűjtő medence körül és a tölgy, szil, bükk, gyertyán, nyír, éger pollenek folyamatos (bár elenyésző) jelenléte alapján vegyeslombozatú tajga vehette körül a medencét. A tajga kifejlődése egyértelműen zárt volt és nem zárható ki, hogy a tajgaerdő a nedves aljzatú medencét töltötte ki.

A tajgát kisebb vizes, sással, tündérrózsával bevont sekély mélységü, nyáron gyorsan felmelegedő tocsogó szakíthatta meg. A füves és libatoppal borított területek aránya, a Kárpát-medence jégkor végi más területeivel szemben minimális volt. Kiterjedt füves térségekre a pollenösszetétel nyomán a vizsgált területen nem következtethetünk. Ennek nyomán a terület vegetáció fejlődése eltér a magyarországi pollenszelvények döntő többségétől 


\begin{tabular}{|c|c|c|c|}
\hline $\begin{array}{l}\text { Mélység } \\
(\mathrm{cm})\end{array}$ & Pollenzóna & $\begin{array}{l}\text { Pollen } \\
\text { alzóna }\end{array}$ & Pollenzóna jellemzői \\
\hline $0-12$ & \multirow{7}{*}{ BTM-3 } & BTM-3g & $\begin{array}{c}\text { Tölgy - nyír - éger - gyertyán - bükk dominanciájú erdő fejlődött } \\
\text { ki a területen, alárendelten hárssal és szillel keverten. AP } \\
\text { együttes aránya meghaladja a } 90 \% \text {-ot a XIX. és XX. század } \\
\text { során. }\end{array}$ \\
\hline $12-22$ & & BTM-3f & $\begin{array}{l}\text { Erdöirtás és irtványok kialakítása a XVIII. század első felében, } \\
\text { mogyoró, hárs és éger terjedése a század második szakaszban }\end{array}$ \\
\hline $22-40$ & & BTM-3e & $\begin{array}{l}\text { Teljes erdöregenerálódás, éger, a nyír, a bükk és a gyertyán } \\
\text { elöretörése, hüvösebb éghajlati szakasz a török korban. }\end{array}$ \\
\hline $40-60$ & & BTM-3d & $\begin{array}{c}\text { Erdőregenerálódást követően újabb erőteljes emberi hatás, } \\
\text { gabona pollenek aránya maximumon, rétekre - legelökre } \\
\text { jellemző pollenek aránya megemelkedet. Emberi hatás } \\
\text { maximumon az Árpádkorban. }\end{array}$ \\
\hline $60-72$ & & BTM-3c & $\begin{array}{c}\text { Fás szárú pollenek arányának erőteljes csökkenése, irtványokra } \\
\text { jellemző nyír, rétekre - legelökre jellemzö gyomok arányának } \\
\text { erőteljes növekedése - állattartó övezet a láp körül. }\end{array}$ \\
\hline $72-92$ & & BTM-3b & $\begin{array}{l}\text { Hárs, szil, tölgy, mogyoró, gabona pollenarányának erőteljes } \\
\text { növekedése a késő-vaskorban és a császárkor kezdetén. }\end{array}$ \\
\hline $92-108$ & & BTM-3a & $\begin{array}{l}\text { Lombosfa dominancia, gabona pollenek jelenléte, nyír, } \\
\text { éger, bükk, gyertyán arány a jelentősebb a kora és középső } \\
\text { vaskorban. }\end{array}$ \\
\hline $108-130$ & BTM-2 & & $\begin{array}{c}\text { Jégkor végi, vegyeslombozatú tajgavegetáció, fenyőfélék } \\
\text { dominanciájával, nyír - éger pollenek aránya jelentősen } \\
\text { megemelkedett. }\end{array}$ \\
\hline $130-260$ & BTP-1 & & $\begin{array}{c}\text { Jégkori, vegyeslombozatú tajgavegetáció, fenyőfélék } \\
\text { dominanciájával, lokális erdei fenyő jelenléttel. Lágyszárú } \\
\text { pollenek jelenléte minimális ebben a szintben. }\end{array}$ \\
\hline
\end{tabular}

5. táblázat: A Baláta-tóból kiemelt fúrásszelvény pollenzónái.

Table 5.: The pollen zones from the analysed core sequence of Lake Baláta.

BAP-2 (108-130 cm)

$130 \mathrm{~cm}$-nél megváltozott a pollenösszetétel, bár továbbra is a fenyőfélék dominálnak (80-85\%) és ennek nyomán a tajga növényzet volt a meghatározó, de a nyír és az éger elöretörése nyomán már enyhébb éghajlatra, fenyő - nyír - éger alkotta, medencét kitöltő mocsári erdőkre következtethettünk. A füfélék, libatopfélék, sásfélék aránya, bár ciklikusan megemelkedik, továbbra is alárendelt.

Magyarországi szelvények közül a mezőlaki (SüMEGl et al. 2009) szelvény esetében mutatható ki párhuzama ennek a pollenösszetételnek. A pollen összetétel nyomán a jégkor befejező szakaszával párhuzamosítható ez a szint.

\section{BAP-3 (108 cm-től a felszínig)}

JUHÁsz (2007) megállapításival szemben egyetlen pollenzónát lehetett lehatárolni a szelvény holocén szakaszában, bár ez harmadik pollenzóna nem egységes, alzónákra osztható a kisebb változások alapján. $\mathrm{Az}$ itt tárgyalt alzónák kifejlődése, pollen összetétele, az egyes taxonok jelenléte, megjelenése és visszaszorulása jelentős különbséget mutat a Juhász (2007) által közölt anyagokhoz képest.

BAP-3a alzóna (108-92 cm között)

A fásszárú fajok aránya dominál (80 \% felett), de termofilabb jellegű hárs, szil, tölgy, mogyoró aránya a pollenanyagban alárendeltebb, a bükk, gyertyán, nyír és éger erőteljesebb ebben a szintben. A radiokarbon adatok alapján a kora és a középső vaskornak, időszámítás előtti IX. és III. század közötti időintervallumnak felel meg ez a horizont (VADAY, 2004).

Ebben az időhorizontban a Hallstatt kultúra, majd történelmi népek, a pannonok és a kelták jelenlétét valószínűsíthetjük a vizsgált térségben a régészeti és történelmi források alapján. A pollenösszetétel alapján egy relatíve humidusabb, hűvösebb éghajlati szakaszt rekonstruálhatunk ebben a kronológiai szakaszban.

Valószínűsíthető, hogy az óceáni éghajlati hatás erőteljesebben jelentkezhetett ebben a periódusban, a nyári és a téli félév közötti hőmérsékleti különbségek 
mérséklődtek, a vegetációs periódus hőösszege, az éves hőingás mértéke lecsökkent. Az alzóna jellemzöje, hogy a gabonatermesztésre utaló pollen anyag már megjelent.

\section{BAP-3b alzóna (92-72 cm között)}

A fásszárú fajok aránya dominál (80\% felett) továbbra is. A termofilabb jellegű hárs, szil, tölgy, mogyoró aránya a pollenanyagban elöre törtek, a bükk, gyertyán, nyír és éger aránya lecsökkent. A radiokarbon adatok alapján, időszámítás előtti II. és az időszámítás után V. század közötti időintervallumnak, a késő vaskornak és a császárkornak felel meg ez a horizont (VADAY, 2004).

Ebben az időhorizontban a pannonok, kelták, majd rómaiak, valamint romanizált lakosság jelenlétét valószínűsíthetjük a vizsgált térségben a régészeti és történelmi források alapján. A pollenösszetétel alapján egy relatíve enyhébb és talán szárazabb éghajlati szakaszt rekonstruálhatunk ebben az időhorizontban. Valószínűsíthető, hogy a szubmediterrán éghajlati hatás, amely ma is egyértelmüen jelentkezik a területen (5. ábra) ebben az időben is felerösödhetett, és esetleg a kontinentális éghajlati hatással kombinálódhatott, ezzel párhuzamosan az óceáni éghajlati hatás lecsökkenhetett.

Így egy enyhébb és szárazabb vegetációs periódusokkal jellemezhető éghajlati szakaszt rekonstruálhatunk. A gyomok, a gabona pollenek jelenléte alapján szántóföldi növénytermesztés is kialakulhatott a vizsgált térségben, de szerepe alárendelt lehetett, mert a pollenösszetétel (80\% feletti fásszárú növények pollenanyaga) alapján a környező területeken, az üledékgyűjtő medence méretét figyelembe véve mintegy $10 \mathrm{~km}^{2}$-es területen a lombos erdő volt az uralkodó növényzet.

\section{BAP-3c alzóna (72-60 cm között)}

A fásszárú fajok aránya lecsökken (60 \% felett), bár még így is domináns marad. Az enyhébb éghajlatra utaló fás szárúak, mint a hárs, a szil, a tölgy, a mogyoró aránya a pollenanyagban visszaszorulnak, a nyír aránya eröteljesen megemelkedik. A radiokarbon adatok alapján, időszámítás után III. és az X. század közötti időintervallumnak, a késő-császárkornak és a népvándorláskornak felel meg ez a horizont (VADAY, 2004).

Ebben az időhorizontban a romanizált lakosság, ezt követően különböző germán törzsek, avarok, majd frankok jelenlétét feltételezhetjük a vizsgált térségben a történelmi források alapján. A pollenösszetétel egy jelentősebbnek mondható erdőirtás kialakulását valószínüsíti, amelynek irtványán a nyír terjedhetett. A sásfélék és libatopfélék terjedése is az erdőirtás, a nyílt területek, rétek kialakítását valószínűsíti, valamint azt, hogy ezeket az irtványokat állattenyésztésre és legelőén, kaszálóként hasznosíthatták, bár a gabonafélék arányának kisebb mértékü növekedése a szántóföldi kultúra erőteljesebbé válását jelezheti.

Az éghajlati feltételekre a vízi környezetet igénylő Nymphaea arányának növekedése utalhat. Ez alapján egy csapadékosabb szakasz rajzolódik ki a népvándorláskorban és a pollenanyagban nem sikerült kimutatni a Krisztus után VIII. századra keltezett enyhébb és szárazabb periódust, sőt a népvándorláskor végén (VIII-X. század) egy visszaerdősülési folyamatot figyelhetünk meg. Így csapadékosabb vegetációs periódusokkal jellemezhető éghajlati szakaszt rekonstruálhatunk a népvándorláskorban.

Ugyanakkor a gyomok, sásfélék, a gabona pollenek arányának növekedése alapján szántóföldi növénytermesztés, de elsősorban az állattenyésztés erőteljesebbé vált a vizsgált térségben, az erdei növényzet pollenjeinek erőteljesebb (80 \%-ról 60 \%-ra) csökkenése nyomán rekonstruált irtványokon. A késő-császárkori/ kora népvándorlás kori gazdálkodás előretörése a népvándorláskor végén visszaesett, a IX században a fásszárú növényekből származó pollenek aránya ismét meghaladja a 80 \%-ot.

\section{BAP-3d alzóna (60-40cm között)}

A radiokarbon vizsgálat alapján a magyar honfoglalást követő évszázadokban alakult a vizsgált terület tágabb térségében a legerőteljesebb emberi hatás. A fás szárú növényekből származó pollen aránya több száz éven keresztül (XI-XV. század között) 40-50 \% közé csökkent, a gabona pollenek aránya a szelvényen belül ekkor éri el a maximumát, a gyomvegetáció, sás, nád és gyékény egyaránt elöretört.

A tavi rendszer lápos tóvá, aktív tőzegképző környezetté alakult az Árpádkor folyamán. Nem zárható ki, hogy a tó környezetében kifejlődött erdei környezet erőteljes bolygatása nyomán felgyorsult erózió és feliszapolódás is szerepet játszhatott a lápos tavi állapot kialakulásának az aktív tőzegképző láprendszer kifejlődésének.

BAP-3e alzóna (40-22 cm között)

AXV. századtól a pollenösszetétel erőteljesen megváltozott. A gabonafélék, gyomok, egyáltalán az emberi hatást jelző elemek visszaszorultak és az erdőre jellemző pollenek (Arbor Pollen) aránya ismét meghaladta a 80 \%-ot. A fák közül az éger, a nyír, a bükk és a gyertyán tört elöre. Ennek nyomán a XV-XVIII. század között egy hüvösebb és mindenképpen csapadékosabb éghajlati szakasz rajzolódott ki a vizsgált területen.

BAP-3f alzóna (22-12 cm között)

A pollen alzóna az ülepedési ráta, a mélység - kor modell alapján valószínüleg XVIII. századnak felelt meg. A század első évtizedében jellegzetes erdőirtási szint alakult ki (22-20 cm között), gabonafélék és a legeltetés, taposás nyomán terjedő gyomok dominanciájának növekedésével, majd az irtványokon terjedő heliofil mogyoró, hárs és éger pollenaránya növekedett meg. Erőteljes emberi hatások alatt állt a terület és valószínűleg ez jellemezte a XVIII. század jelentős részét. A vegetáció összetétele alapján a XVIII. század második felében egy relatíve enyhébb szakasz rajzolódik ki.

BAP-3g alzóna (12 cm-töl a felszínig)

Ezt követően, valószínüleg a XIX. század kezdetétől egy tölgy - nyír - éger - gyertyán - bükk dominanciájú erdő fejlődött ki a területen, alárendelten hárs- 
sal és szillel keverten. Az AP pollenek együttes arány meghaladta a $90 \%$-ot. A pollenösszetétel alapján egy hủvösebb-csapadékosabb éghajlati fázis alakult ki a XIX. században és a XX. század folyamán az éger, nyír visszaszorulása, a tölgy, szil, gyertyán és a bükk előtérbe kerülés figyelhető meg.

\section{Az eredmények értékelése}

A Baláta-tavi rendszerének változását a fúrás szedimentológiai, geokémiai változásai, valamint a makrobotanikai és pollenanalitikai anyag alapján tudjuk rekonstruálni. A környezettörténeti adatok alapján két igen eltérő őskörnyezeti fejlődési állapot alakult ki a vizsgált medencében.

\section{Jégkori környezet}

Az üledékréteg kifejlődése és a pollenösszetétel alapján a 260 és $108 \mathrm{~cm}$ közötti szakasz a jégkorban, a pleisztocén végén valószínűleg a késő-glaciális periódusban 18 ezer és 12 ezer cal BP évek (Krisztus előtti $X V I$. és XI. évezred) között fejlődött ki. A rétegtani párhuzamosítást a szegedi - öthalmi lelőhelyen a homokbuckák mélyedésében felhalmozódott, radiokarbon vizsgálatokkal korolt infúziós löszréteg tette lehetővé. A jégkori üledékréteg kifejlődése, szemcseösszetétele és vízoldható elemtartalma alapján a Baláta-tó medencéjében a jégkor végén egy magas talajvízállású terület fejlődhetett ki, amelyben az alföldi infúziós löszre (SüMEGI, 2005) emlékeztető üledék halmozódott fel. Az üledékből makrobotanikai anyag nem került elő és Mollusca héjakat sem sikerült kinyerni a fúrásnak ebből a szakaszából.

Ugyanakkor jó és közepesen jó megtartású pollenanyag került elő ebből a szintböl. A pollenanyag öszszetétele alapján az egyértelmüen jégkori (pleisztocén végi) rétegekben a fásszárú növények mindenekelőtt a fenyőfélék dominálnak (60-85 \%). Ez alapján az erdei fenyő egyértelműen erdőalkotó lehetett a vizsgált üledékgyűjtő medence körül, egészen pontosan a medence mélyebb részén lehetett tajga erdő. A széles- és keskenylevelü lombhullató fák, a tölgy, szil, bükk, gyertyán, nyír, éger pollenek folyamatos (bár elenyésző) jelenléte alapján vegyeslombozatú tajga vehette körül, illetve boríthatta a medencét.

A tajga vegetáció összetételében egy jelentősebb változás is kimutatható volt, bár továbbra is fenyőfélék domináltak, de a nyír és az éger elöretörése nyomán már enyhébb éghajlatra, fenyő - nyír - éger alkotta, medencét kitöltő mocsári erdőkre következtethettünk. Ennek nyomán a jégkor befejező, késő glaciális szakaszával párhuzamosítható ez a pollenszint, míg az előző pollenösszetétel a jégkor végének, alpi nevezéktan szerinti felső-würm, a németalföldi elnevezés szerinti késő-pleniglaciális végével, a jégkor egyik legerőteljesebb hidegmaximumával, az ún. LGM (Last Glacial Maximum) horizontjával párhuzamosítható.

A jégkori környezet korának pontosabb meghatározásához speciális radiokarbon vizsgálatok szükségesek, mert a pollenanyagot beágyazó üledék szerves anyag tartalma rendkívül alacsony. Ugyanakkor, ha korrekt korelemzéssel sikerülne igazolni, hogy a jégkori üledékes összlet a legutolsó glaciális legjelentősebb lehülés során halmozódott fel, akkor egyértelműen bizonyítható lenne a termomezofil fák (tölgy, bükk) pollenjeinek folyamatos, bár alacsony jelenléte nyomán, hogy a területen erdőrefúgium fejlődött ki a pleisztocén folyamán. Jelenleg a rétegtani bizonytalanságok, radiokarbon adatok hiánya miatt ez az erdörefúgium modell erősen hipotetikus.

A mocsári környezetben felhalmozódott mállatlan szilikátokat tartalmazó, kőzetlisztben gazdag jégkor végi réteg kialakulását követően valószínüleg a Krisztus előtti XI. évezredtől a Krisztus előtti I. évezred kezdetéig a vizsgált szelvényben nem halmozódott fel üledék. Valószínűsíthető, hogy az üledékgyűjtő medence kiszáradhatott. A kiszáradást okozhatta jégkor végén kifejlődött hidrológiai rendszer drasztikus megváltozása, a talajvízáramlás átalakulása és legvalószínübbnek tünik, hogy a dunántúli területen bizonyított örökfagy (permafroszt) réteg kiolvadása, a tómedence aljzat vízáteresztő képességének ugrásszerü növekedése okozhatta tómedence kiszáradását.

Nem zárható ki, hogy a Baláta-tó medrétől délkeletre található, a Baláta-tónál mélyebb helyzetü, az 1784-ben készült térképen még mocsárként jelölt és Palád-tónak nevezett, mai nevén Menic-rét területén a holocén korai szakaszában tavi rendszer fejlődött ki és ez a tó a holocén második felére feltöltődött. Így a Baláta tavon ma megtalálható jégkor végére és holocén kezdetére jellemző növények esetleg innen települhettek át a késő holocén folyamán a kialakuló tavi rendszerbe.

\section{Késő holocén környezet}

A Krisztus elötti I. évezred kezdetén kialakult tavi állapot legalább annyira problematikus, mint a medence feltételezett jégkor végi kiszáradása, de sem a medence északi, sem a déli felén lemélyített, öszszesen mintegy 20 fúrásban nem lehetett a holocén idősebb szakaszában felhalmozódott tavi, vagy lápi üledéket kimutatni. Ugyanakkor a késő-holocén során felhalmozódott eutróf tavi és lápos tavi üledékeket a tómedence szinte minden részén sikerült feltárni. Feltételezhető, hogy a holocén kései szakaszára töltődött fel olyan szintre a belső-somogyi hordalékkúp hidrogeológiai rendszere, hogy a talajvíz a felszínre lépett vadvíz formájában és ennek nyomán tavak - mocsarak alakulhattak ki a hordalékkúp jégkor során kialakult mélyebb részein (szélbarázdák, széllyukak, kifúvásos mélyedések). Mivel a terület hidrogeológiai rendszere jelenleg még feltáratlan, ezért csak hipotéziseket állíthatnánk fel, hogy miért alakult ki a vaskori feltöltődése a talajvízrendszernek. A hipotézisek generálása helyett a vaskortól a területen lejátszódott környezettörténeti változásokat rekonstruáltuk régészeti korok szerint az erdőfejlődésre és az éghajlatváltozásra koncentrálva. 


\section{Kora és középső vaskor}

A Krisztus előtti első évezredben kifejlődött tavi és lápos tavi képződmények a kora vaskorban indultak felhalmozódásnak és a geokémiai-üledékföldtani paraméterek alapján a fúrás környezetében sekélytavi körülmények alakultak ki ekkor. Az üledékföldtani, geokémiai és pollenanalitikai eredmények mellett makrobotanikai anyagok is rendelkezésünkre álltak. A makrobotanikai anyag összetételét hasonlítottuk öszsze a terület jelenlegi vegetációjával (BORHIDI - JÁRAIKomLóDI 1959a,b; BoRHIDI 1970) akkor láthatjuk, hogy a nagy felületű sekélytavat (a BTM-1 zónát) leszámítva a fúrásban feltárt növény asszociációknak megfelelő valamennyi vegetáció típus recensen is megfigyelhető a terület különböző részein, bizonyos szabályszerüségek szerint elrendeződve.

A kora vaskori tiszta felszínü, növényzettel nem borított mintegy 2 méteres vízmélységủ tóval kitöltött medencét nyír - gyertyán - éger - bükk dominanciájú erdők vették körül (14. ábra), de a gabona pollenek aránya is relatíve jelentős volt. A tó vizének oldott vas, kálium és nátrium tartalma igen jelentős és szerves anyagban relatíve gazdag volt, vizének minősége így mezotróf lehetett. A pollen összetétel alapján a partot keskeny nádas, gyékényes társulás övezhette helyenként lebegő, és gyökerező hínártársulásokkal (fehér tündérrózsa, süllőhínár, sárga vízitök) keverve.

A szedimentológiai, geokémiai, makrobotanikai és pollenanalitikai eredmények (12. és 13. ábra) által egy- aránt kirajzolódó kora vaskori tavi szakasz a Baláta-tó medencéjében jól szinkronizálható a jégtakaró elemzések nyomán rekonstruált globálisan jelentkező hűvösebb, csapadékosabb horizonttal, a svájci tavak vízszintjének erőteljes megemelkedésével (MAGNY et al. 1995), az alpi gleccserek (HoLzHAUSER et al 2005) elöretörésével (14. ábra). Az is egyértelmü, hogy a proxy adataink nem jeleznek vízszintváltozásokat a kialakult Baláta-tóban és olyan szintü éghajlati és csapadék bevételi változásokra nem következtethetünk, mint a svájci tavak elemzése nyomán (14. ábra) kirajzolódtak a kora vaskorban.

A Baláta-tó medencéjében a kora vaskorban kialakult tavi fázis egészen a császárkor második feléig, a Krisztus után III. századig változatlan maradt, függetlenül a közép-európai területeken, illetve globálisan a vaskorban kimutatott igen jelentős hőmérsékleti változásoktól (MAGNY, 2004) és csapadék fluktuációtól.

A baláta tavi kora és középső vaskori pollen eredmények sem jeleztek erőteljes éghajlati változást, mindössze az emberi hatások változását, egy kora vaskori (késő-bronzkori?) jelentősebb kiterjedésű erdőirtás utáni, Krisztus előtti VI. és IV. évszázad közé tehető erdöregenerálódási folyamatot (14. és 15. ábra). Ez az erdőregenerálódási folyamat különösen a 15. ábrán szembe tűnő, ahol az adott minta időbeli felhalmozódását is figyelembe vettük az ülepedési ráta alapján.

A pollenösszetétel (DAvis et al. 2001) nyomán a kora- és középső-vaskorban a napjainkban a területen jelentkező mintegy 710-720 mm csapadékot erőtelje-

\begin{tabular}{|c|c|c|c|c|}
\hline $\mathrm{cm}$ & $\begin{array}{l}\text { KOR } \\
\text { BP év }\end{array}$ & $\begin{array}{l}\text { SZEDIMENT- } \\
\text { GEOKÉMIA }\end{array}$ & POLLEN & MAKROBOTANIKA \\
\hline & \multirow{5}{*}{$\begin{array}{l}=375 \pm 40 \\
=645 \pm 30 \\
=995 \pm 30 \\
=2140 \pm 30\end{array}$} & \multirow{2}{*}{$\begin{array}{c}\text { Th4 } \\
\text { Szerves anyag, } \\
\text { vízoldható Ca-, Mg- } \\
\text { maximum }\end{array}$} & \multirow{2}{*}{ 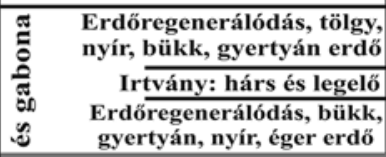 } & $\begin{array}{l}\text { Füz-, zsombékos, harmatkásás } \\
\text { nád- és gyékényes lápfoltok, } \\
\text { ciklikusan kiszáradó semlyékek }\end{array}$ \\
\hline & & & & $\begin{array}{l}\text { Tózzegégés, majd vízszintemelkedés, } \\
\text { zárt gyékény - nád - harmatkásás láp }\end{array}$ \\
\hline & & As2Sh2 K-maximum & Erdöregenerálódás, majd & Zsombéksás terjedés, láposodás \\
\hline & & Th2Tb2 & $\begin{array}{l}\text { emberi hatás maximum } \\
\text { Irtvány: nyír és legelö }\end{array}$ & Náddal borított úszóláp állapot \\
\hline & & As3Th1 & $\begin{array}{l}\text { Mogyoró, hárs, tölgy, szil, } \\
\text { és gabona elöretörés }\end{array}$ & $\begin{array}{l}\text { Harmatkásás, gyékényes, nádas } \\
\text { mozaikok, ciklikus kiszáradás }\end{array}$ \\
\hline \multirow[t]{3}{*}{100} & \multirow[t]{4}{*}{$=2425 \pm 30$} & As3Sh1 & $\begin{array}{l}\text { Holocén nyír - gyertyán - } \\
\text { éger - bükk - tölgy - hárs erdô }\end{array}$ & Sekélytavi állapot \\
\hline & & $\begin{array}{l}\text { Vízoldható Fe-, K- } \\
\text { tartalom növekedett }\end{array}$ & \begin{tabular}{|c|} 
Jégkori fenyö - nyír- éger \\
összetételü ligeterdö
\end{tabular} & \multirow{3}{*}{$\begin{array}{l}\text { Nem került elő } \\
\text { makrobotanikai } \\
\text { anyag }\end{array}$} \\
\hline & & $\begin{array}{c}\text { Ag3As1 } \\
\text { Szervetlen anyag } \\
\text { tartalom jelentős, } \\
\text { karbonátos anyag } \\
\text { jelenléte, vízoldható } \\
\text { Ca-, Mg - tartalom } \\
\text { jelentős }\end{array}$ & \multirow{2}{*}{$\begin{array}{c}\text { Vegyeslombozatú } \\
\text { jégkori tajga, fenyő } \\
\text { dominanciával, } \\
\text { lokális erdei fenyövel, } \\
\text { alárendelten, de } \\
\text { folyamatosan jelenlévő } \\
\text { termomezofil fákkal } \\
\text { (tölgy, szil, bükk, éger, } \\
\text { gyertyán, nyír), } \\
\text { ártéri ligeterdő jellegü } \\
\text { kifejlödés }\end{array}$} & \\
\hline 200 & & $\begin{array}{l}\text { Ga4 } \\
\text { anyag maximum } \\
\text { Ag3G1 }\end{array}$ & & \\
\hline
\end{tabular}

12. ábra: A Baláta-tavi III. fúrásszelvény környezettörténeti változásai (Sümegi, 2009).

Fig.12.: Environmental historical data changes in the basin of Baláta lake and its environ during the last 3000 years (Sümegi, 2009). 

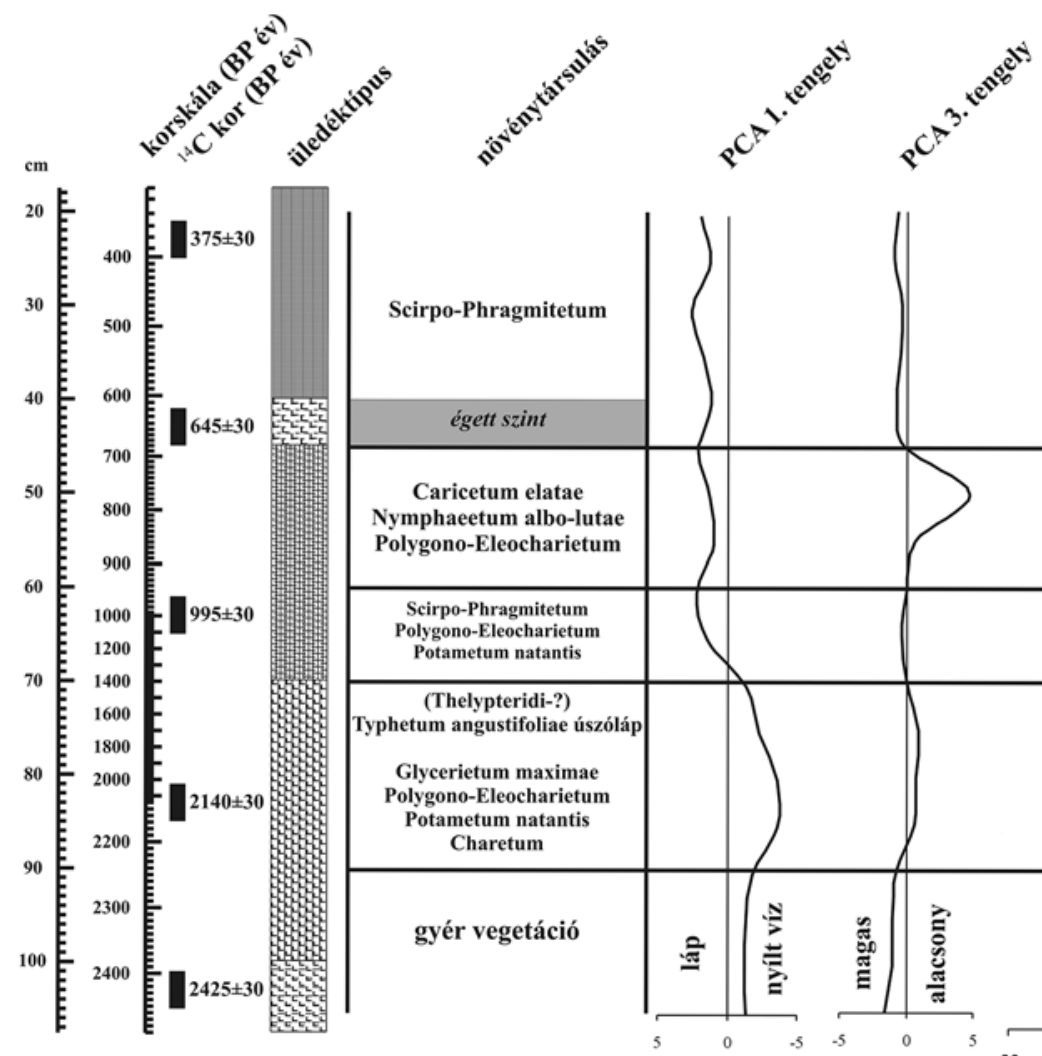

növényzet borítása
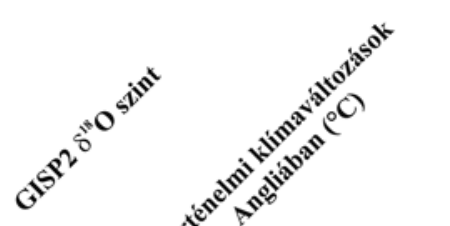


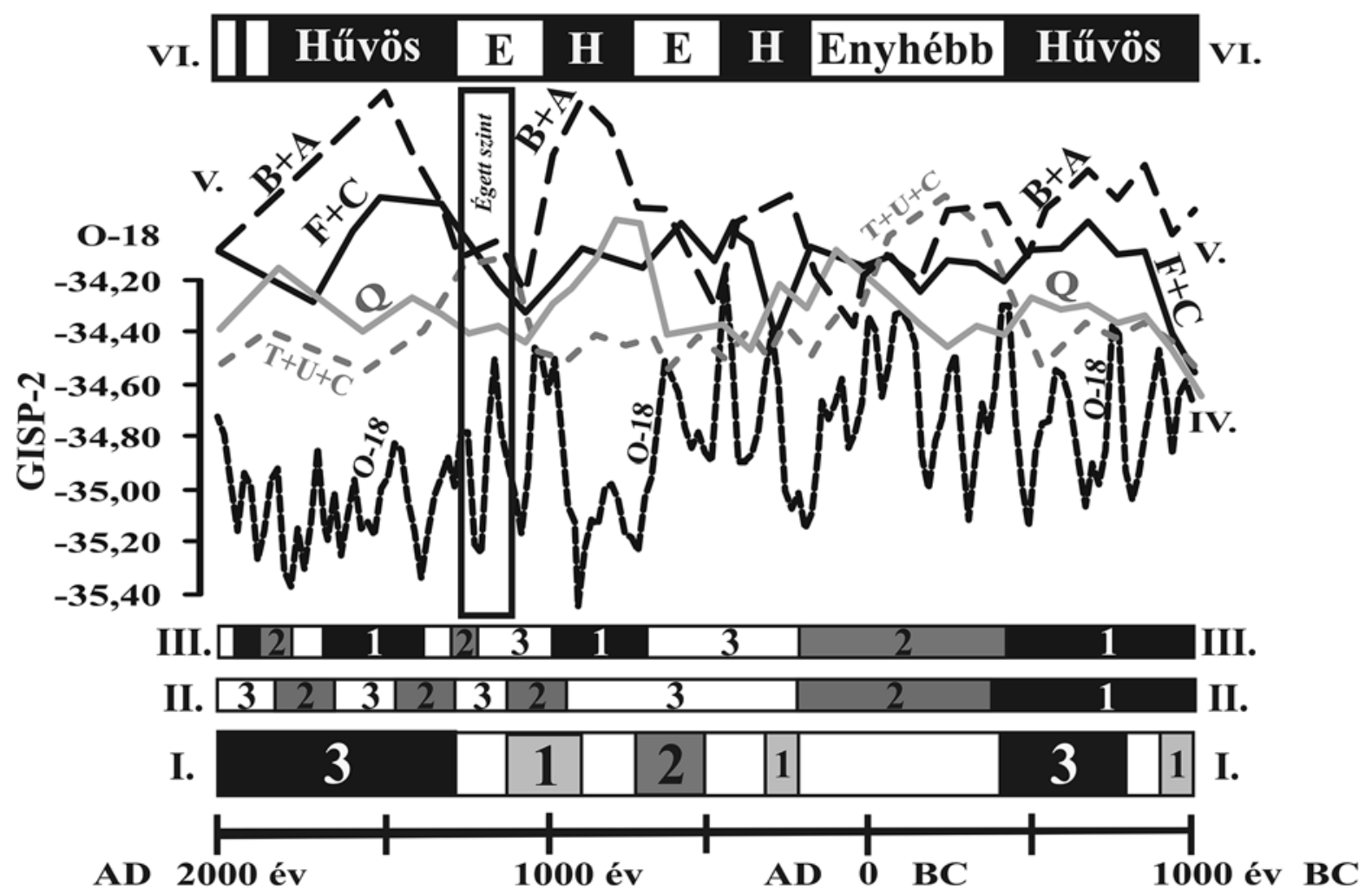

14. ábra: A Baláta-tó déli medencéjében és környezetében lejátszódott környezettörténeti változások összehasonlító elemzése és értékelése az utolsó 3000 évben (Sümegi, 2009)

I. Svájci tavak vízszintjének változásai (Magny munkái nyomán): 1. Egyméteres vízszintemelkedések, 2. Kétméteres vízszintemelkedések, 3. Háromméteres vízszintemelkedések, Fehér szakaszok = vízszintcsökkenések II. Baláta tó vízszint változása makrobotanikai anyag alapján: 1. Nyílt vízi állapot, 2. Lápos tavi állapot, 3. Láp állapot, III. Terresztris növényzeti változás pollen összetétel alapján: 1 = bükk - gyertyán - éger és nyír dominanciájú erdők, 2 = hárs - szil - mogyoró és tölgy dominanciájú erdők IV. GISP 2 fúrás oxigénizotóp változása

V. Pollenösszetétel dominancia változása megközelítőleg 100 éves felbontásban $B+A=B e t u l a$ (nyír) és Alnus (éger), $F+C=$ Fagus (bükk) és Carpinus (gyertyán), $Q=$ Quercus (tölgy), $T+U+C=$ Tilia (hárs), Ulmus (szil) és Corylus (mogyoró)

VI. Baláta tó III. fúrásszelvényéből elökerült pollenek alapján készült hőmérséklet rekonstrukció (Davis et al. 2001, 2003 és Magyari, 2002).

Fig.14.: Reconstructed climatic and vegetation changes in the basin and environ of the Balata lake during the last 3000 years (Sümegi, 2009)

I. Swiss lakes level changes (based on Magny's papers): 1= one meter increasing lake level, 2 = two meter increasing lake level, 3 = three meter increasing lake level, white parts = lake level decreasings.

II. Lake level changes of the lake Baláta based on macrobotanical remains: $1=$ Open water surface, $2=$ Floating mate stage, 3 = Peatland stage

III. Terrestrial vegetation change based on pollen data: 1 = beech - hornbeam - alder - birch forest dominance phase 2 = lime - elm - hazel - oak forest dominance phase

IV. Oxygene isotope change in the GISP 2 core sequence during last 3000 years

V. Pollen content dominance change: $B+A=$ Betula (birch) és Alnus (alder), $F+C=$ Fagus (beech) és Carpinus (hornbeam), $Q=$ Quercus (oak), $T+U+C=$ Tilia (lime), Ulmus (elm), Corylus (hazel)

VI. Pollen-based climatic recontruction of the analysed sequence in the Baláta lake (based on Davis et al. 2001, 2003 and Magyari, 2002). 

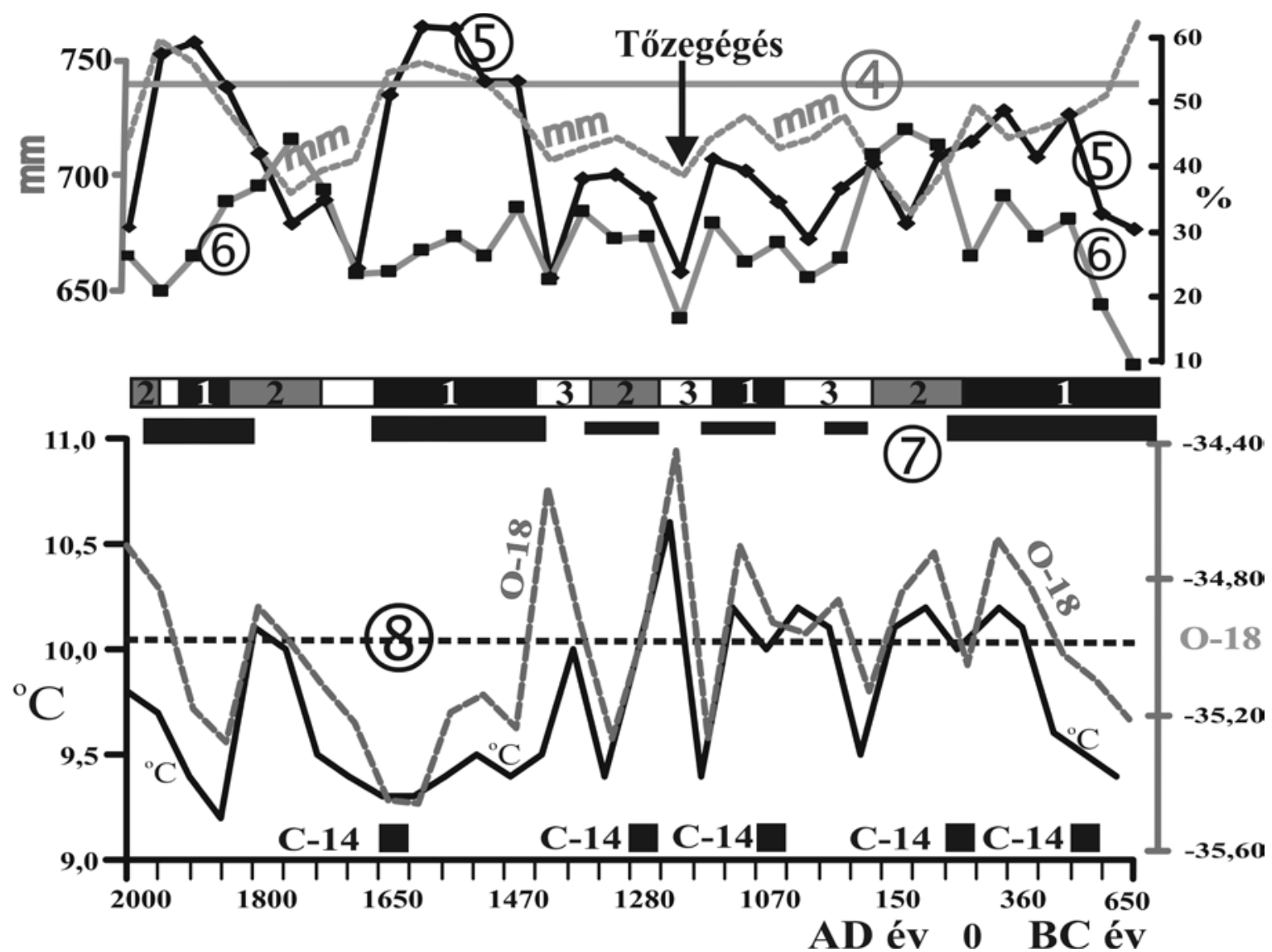

15. ábra: A Baláta-tó déli medencéjében és környezetében lejátszódott éghajlati és növényzeti változások öszszehasonlító elemzése és értékelése az utolsó 3000 évben (Sümegi, 2009)

1. Nyílt vizü tó, 2. Lápos tó, 3. Láp, 4. Évi csapadékbevétel 3000 éves átlaga, 5. Bükk, éger, nyír, gyertyán fák pollendominanciájának együttes változása, 6. Hárs, szil, tölgy és mogyoró pollendominanciájának együttes változása, 7. Csapadékos klímaszakaszok Baláta-tó környezetében, 8. Évi középhőmérséklet 3000 éves átlaga.

Fig.15.: Reconstructed climatic and vegetation changes in the basin and environ of the Baláta lake during the last 3000 years (Sümegi, 2009)

1 = open lake stage, 2 = floating mat stage, 3 = peatland stage, 4 = reconstructed annual fall overage during last 3000 years, $5=$ summa dominance change of the beech, alder, bich and hornbeam pollens, $6=$ summa dominance change of the lime, elm, oak and hazel pollens, $7=$ rainy climatic phase, $8=$ reconstructed annual

temperate overage during last 3000 years, $0-18=$ Oxygene isotope change in the GISP 2 core sequence during last 3000 years.

mérséklet, és elsősorban a tenyészidőszak hőösszege jelentős mértékben megemelkedett, meghaladta a mai szintet és az elmúlt 3000 év átlagát (14. és 15. ábra). Mivel a vaskor végén a csapadékbevétel még nem csökkent le jelentős mértékben, így hárs - szil - tölgy - mogyoró dominanciával jellemezhető erdő fejlődött ki a Baláta-tó körül.

Ez az enyhébb éghajlati szakasz átfogja a késő-vaskor végét és a császárkor kezdetét is és jól szinkronizálható a jégtakarót feltáró fúrásszelvényeken mért oxigénizotóp eltolódással (DANSGAARD et al. 1993, GROOTES et al. 1993), a svájci tavak vízszintjének csökkenésével (MAGNY, 2004), a gleccserek viszszahúzódásával (HolzHAuser et al 2005). A pollenösszetétel nyomán számított évi középhőmérséklet ebben a szakaszban meghaladta napjaink évi középhőmérsékletét $\left(9,8^{\circ} \mathrm{C}\right)$ és az utolsó 3000 év átlagos évi középhőmérsékletének megfelelő lehetett (10,0 - $\left.10,1^{\circ} \mathrm{C}\right)$. Ezzel párhuzamosan a késő-vaskorban a kora vaskorra jellemző csapadékviszonyok is megváltoztak, a csapadék mennyisége mintegy 40-50 mm-rel lecsökkent a kora vaskorhoz képest és $730-740 \mathrm{~mm} /$ év között mozoghatott a vaskor végén. A tenyészidőszak hőösszege megemelkedett, a $10{ }^{\circ} \mathrm{C}$ fok feletti tavaszi napok száma, amely ma a területen 240-260 nap, megnövekedhetett, és a tenyészidőszak kezdete március kezdetére tolódhatott el. Ez a római optimumnak is nevezett késő-vaskori - császárkori éghajlati szakasz kedvező helyzetet teremtett a közép-európai térségben a mezőgazdaság fejlődéséhez. 


\section{Császárkor}

A késő-vaskorban mozaikosan kifejlődött vízi vegetáció, a lápos tavi állapot a császárkorban is fennmaradt, sőt a császárkor második felében a harmatkásás - gyékényes - nádas lápok elboríthatták a Baláta-tó déli medencéjének jelentős részét. A zárt láp kialakulását igen sokféleképpen magyarázhatjuk, gondolhatnánk a belső szukcessziós folyamatokra is, de kiemelkedő jelentőségű a láposodás megértése szempontjából, hogy a császárkor kezdetén a vizsgált üledékgyűjtő medencét még hárs - szil - mogyoró és tölgy dominanciájú erdő vette körül. Ugyanakkor a Krisztus utáni III.-V. század között, a láposodás kezdetén, a fásszárú pollen anyag drasztikusan lecsökkent.

Olyan egyértelműen összekapcsolódik a láposodás kezdete és a fásszárú pollenanyag drasztikus csökkenése (12., 13., 14. és 15. ábra), hogy ennek nyomán feltételezzük az erdőirtás nyomán kialakult talajbemosódást, eutrófizálódást, a medence teljes elláposodását. Ezt a folyamatot elősegíthette, hogy a császárkor kezdetén a csapadékbevétel tovább csökkent a kora vaskori csapadékmaximumhoz képest és ebben a viszonylag enyhe, az utolsó 3000 év átlagát és a mai átlagos évi középhőmérsékletet meghaladó $10,5^{\circ} \mathrm{C}$ körüli évi középhőmérséklettel jellemezhető éghajlati szakaszban kevesebb, mint $700 \mathrm{~mm}$ csapadék jelentkezett éves szinten.

Bár az időbeli felbontás miatt évszázados szinten nem tudjuk rekonstruálni a Baláta-tó környezetében kialakult környezettörténeti eseményeket az ókor végén, de az egyértelmű, hogy a Krisztus utáni III-IV. évszázadban kialakított erdőirtás nyomán alakult ki a láposodás a medencében. Az erdőirtást követően a pollenöszszetételben jelentősebb arányban lép fel gabonapollen, de még aránynövekedése nyomán nem következtethetünk lokális, a láp közvetlen környezetében kialakított gabonatermesztésre, inkább távolabbi, regionális eredetű behordódásnak tủnik a gabona pollenanyaga. Ugyanakkor a legelő területekre jellemző gyomok, szúrós és mérgező növények pollenaránya sem növekedett meg az erdőirtást követően a pollenszelvényben, így az erdőirtás célja a faanyag kitermelése lehetett, amelyet nem követett szántóföldi és/vagy legelőterületre jellemző hasznosítás a láp közvetlen környezetében a császárkorban. Ugyanakkor a népvándorláskor kezdetén már megjelentek azok a rágást és taposást is elviselö gyomok (föleg libatopfélék) a pollenszelvényben, amelyek nyomán a Krisztus utáni V.-VI. századtól megváltozott területhasznosításra következtethetünk.

\section{Népvándorláskor}

A zárt nád - gyékény - harmatkásás láp állapot változatlanul fennállt a Baláta-tó medencéjében, a császárkor második felében kialakult erdőirtást követően pedig nem történt erdőregeneráció, hanem több száz éven keresztül egy nyitott, elsősorban füvel borított térség jellemezte a láp közvetlen környezetét és a fás szárú növényekre jellemző pollenek aránya a szelvényen belül a legalacsonyabb volt, annak ellenére, hogy egyértelmüen egy csapadékosabb és hűvösebb éghajlati fázis fej- lödött ki. A vizsgált szelvény környékén ekkor 720-740 mm körüli éves csapadékbevétel és $9,5-10,0^{\circ} \mathrm{C}$ közötti évi középhőmérséklet alakult ki. Az előző éghajlati fázishoz képest egy hűvösebb és csapadékosabb éghajlati szakasz alakult ekkor ki. Ennek ellenére a fás szárú növények közül csak az irtványokon terjedő nyír és éger aránya kiemelkedő, ezért feltételezzük, hogy egy jelentős legelöterületet, állattartó övezetet alakítottak ki a láp környezetében. Ez az állattartó övezet a császárkor végén, népvándorláskor kezdetén kifejlődött és valószínüleg a területen megtelepedő különböző germán, majd avar közösségek egyaránt hasznosították. A terület ilyen irányú hasznosítása a Krisztus utáni VIII. században lezárult és gyors erdőregenerálódás alakult ki, a kialakult erdőben a magyar honfoglaláskorra a bükk - gyertyán - éger és a nyír fafajok lettek az uralkodó erdőalkotó elemek. Ugyanakkor a csapadékbevétel növekedése nyomán a láp felszakadozott és lápos tavi állapot alakult ki gyékényes úszóláp és tündérrózsás lápfoltokkal.

\section{Árpádkor és középkor}

Az Árpádkor kezdetére regenerálódott és jelentős kiterjedésü erdőterület az Árpádkorban ismét erőteljesen átalakult. Jelentős kiterjedésű, a lápot övező irtványt alakítottak ki a XI-XIII. század között és az irtványon mind szántóföldi növénytermesztési (gabonatermesztési) övezeteket, mind jelentős kiterjedésü állattenyésztési (legelők, kaszálók) mozaikokat is kialakítottak.

Az igen erőteljes, valamennyi fafajra kiterjedő erdőirtással párhuzamosan a Baláta-tómedencében a honfoglaláskor előtt kifejlődött lápos tó is átalakult és ismét zárt láp, úszó békaszőlő hínárral, iszaptársulásokkal kevert nádassal, valamint zsombéksással borított láp fejlődött ki újra. A mezőgazdasági övezet, az agrártérség kifejlődése egy kifejezetten enyhe és száraz éghajlati szakaszban történt, amikor az évi középhőmérséklet $10,5-11,0^{\circ} \mathrm{C}$ fok közé emelkedett és az évi csapadékbevétel 700-720 mm közöttire csökkent. Ezek az adatok a kontinentalitás fokozódását, a kontinentális és a száraz-mediterrán éghajlati hatás felerősödését jelzik a területen. Ezek a változások a magasabb talajvízállású és magasabb csapadékbevétellel jellemezhető területeken kedvezőbb helyzetet teremtenek a gazdálkodásra, de a szárazabb területeken igen kedvezőtlen helyzetet alakíthattak ki a Kárpát-medence egyes területein.

Ehhez a szinthez kötődik a láp kiszáradása és leégése is (Krisztus utáni XIII. század). Mivel BoRHIDI JÁRAI-KomLÓDI (1959b) vizsgálatai szerint a tó vízszintje, kiszáradása és vízzel való újratöltődése, valamint a különböző klímatípusú évek csapadékjárása között szoros összefüggés mutatható ki, ezért feltételezhető, hogy a XIII. században is hasonló éghajlati hatások fejlődtek ki, mint a napjaink kiszáradásának esetében. BoRHIDI JÁRAI-KOMLÓDI (1959b) elképzelései alapján, ha a nyárvégi arid időszakot mutató szubmediterrán ( $x$ ") és a közepesen száraz - szubmediterrán (xx") típusú évek hosszabb időn keresztül ismétlődnek, vagy a kontinentális éghajlati hatással kombinálódnak, a tó teljesen ki is száradhat, mint az 1941 és 1947 között is megtörtént. 
Úgy tűnik a tó kiszáradását az ilyen szárazszubmediterrán évek ismétlődése, a terület éghajlatában napjainkban is kimutatható kontinentális éghajlati hatás felerősödése, kombinációja okozta a Krisztus utáni XIII. évszázadban (14. és 15. ábra). Ez a kora-középkorra tehető időszak az ún. „Viking Klímaoptimum” ( 1000-1300 AD évek között) (LAMB, 1995), amikor Európa klímája átmenetileg melegebbre fordult. Ezen melegebb időszak globális jellegét bizonyítják a grönlandi jégfúrások oxigén izotópos elemzései is (STUIVER et al. 1995).

Mivel hasonló trendeket tudtunk kimutatni a késő - vaskorban és a császárkor kezdetén ezért feltételezhető, hogy hasonló éghajlati hatások alakulhattak ki a vizsgált térségben a római optimumban is, de ekkor a még juvenilis állapotban lévő tavi környezet láposodása következett be az éghajlati és emberi hatások kombinációjára és nem alakult ki tőzegégés úgy mint a XIII. században.

A lokális és globális éghajlati proxy adatok nyomán hasonló helyzet fejlődhetett ki a XV. század kezdetén, valamint a XVIII. század végén is, de ezekben a periódusokban a csapadék éves mennyiségének erőteljes csökkenése mellett a hömérséklet növekedése nem érte el a XIII. századi szintet, így ezekben a periódusokban nem következett be a tőzegégés, de a tőzeg kiszáradása és tömörödése valószínüleg megtörténhetett. Ugyanakkor ezek az enyhébb és szárazabb szakaszok kifejlődése jól párhuzamosítható a globális felmelegedési szakaszokkal, ha figyelembe vesszük az ülepedési ráta és az éghajlati szakaszok kronológiai párhuzamosításának problematikáját (TELFORD et al. 2004).

Ugyanakkor a kronológiai és éghajlat-történeti párhuzamok mellett igen jelentős eltérések is kimutathatók a proxy adatok alapján mind a Kárpát-medence éghajlati fejlődésében, mind a Baláta-tó környezeti fejlődésében a nyugat- és észak-európai területekhez képest.

A Baláta-tó környezetében a XIII. századi tőzegégést követően a lápos tavi állapot fejlődött ki újra, majd ismét zárt, zsombéksás és nád dominanciájú lápterület fejlődött ki a XV. század második felében. Ezzel párhuzamosan az emberi hatások lecsökkentek a vizsgált területen, ennek nyomán a lakosságszám, valamint az agrártevékenység csökkenésére következtethetünk. Az adatok alapján ez az Baláta-tó környékén jelentkező elnéptelenedési folyamat és gazdasági tevékenység csökkenése már a törökkor előtt megkezdődött és nem a törökkor következménye.

\section{Törökkor}

AXVI. században az elemzett tó környezete az elöző időszakokhoz képest teljesen átalakult. Az emberi hatás minimalizálódott és egy hűvös - csapadékos éghajlati szakaszban $740-760 \mathrm{~mm}$ évi csapadék bevétel mellett $9,3-9,6^{\circ} \mathrm{C}$ évi középhőmérséklet jelentkezett a vizsgált területen. A jelentős csapadékbevétel, a lecsökkent párolgás nyomán zárt bükk - gyertyán - éger - nyír dominanciájú erdők alakultak ki és vették körül a mélyebb fekvésú láposodott területeket. A láp a jelentős vízbevétel következtében felszakadt és újra lápos tavi állapot alakult ki.
A lápos tavi rendszer újraéledése, az aktív tőzegképző nádas - úszóláp - sekélytavi környezet mozaikok kifejlődése, a zsombéksás zóna part ment területre visszaszorulása a XIV. században indult meg, és a tavilápi rendszer ismételt kifejlödése a kis jégkor hűvösebb és csapadékosabb klímaszakaszának kifejlődéséhez, a jelentős mennyiségű csapadék többlet kialakulásához is kapcsolódhatott. A középkor második felétől kezdödően az iszaptársulások, nádas, gyékényes, úszólápi és zsombéksásos társulások térbeli kiterjedései az éves, évtizedes csapadékingadozások függvényében változhattak egészen a XX. századi talajvízszint szabályozásokig, ettől kezdődően az antropogén hatások a meghatározóak a láp fejlődésében.

\section{Újkor}

A lápos tavi rendszer eltérő láp és nyílt vízfelületi aránnyal, de az újkor során is fennmaradt. A felgyorsult feltöltődés következtében, illetve az 1-2 cm mintavétel nyomán 30-40 éves felbontásban lehetett a környezettörténeti változásokat elemezni a Baláta-tó környezetében. Ezen adatok alapján a XVIII. században a török korban kialakult hüvös és csapadékos éghajlati szakaszt megszakította egy jelentősebb felmelegedés, mintegy 100 év alatt a proxy adatok alapján az évi középhőmérséklet $0,5^{\circ} \mathrm{C}$ fokot emelkedett és meghaladta a $10^{\circ} \mathrm{C}$ fokot mintegy $30-50$ éven keresztül. Ezzel párhuzamosan a csapadék mennyisége is elég erőteljesen lecsökkent és a mai csapadékszint alatti 670-680 mm évi csapadékbevétel jelentkezett a területen a XVIII. század végén. A török megszállás után a XVIII. század során erdőirtás vette kezdetét a Baláta-tó környékén és ezt a pollenelemzés alapján levont következtetést már írásos források is alátámasztják (SzABÓ, 2002, 2005).

$A z$ erdőirtást követő enyhébb és szárazabb éghajlati szakaszban hárs - szil - mogyoró dominanciájú erdők fejlődtek ki, de a környezettörténeti adatok alapján nem lehet pontosan megadni, hogy ezek az erdők az irtványokat boríthatták-e be, vagy az éghajlati változás nyomán fejlődtek ki. Annyi bizonyos, hogy a XVIII. század második felében a fás szárú növények pollenaránya meghaladta a $90 \%$.ot, és ez jelentős növekedés a XVIII. század első felében jelentkező 50 \% aránnyal szemben. A XIX. század kezdetén a pollenösszetétel változása nyomán tölgy - gyertyán - éger - nyír bükkfák uralta erdő alakult ki, amelyben a XX. századra a tölgy pollenek aránya egyre dominánsabb jellegűvé vált, ennek nyomán a tölgy előtérbe kerülése zajlott az elmúlt 100-120 évben a vizsgált terület erdeiben.

A XX. századi pollenösszetétel alapján számolt évi középhőmérséklet $9,7^{\circ} \mathrm{C}$ foknak, míg a csapadék 720 mm-nek adódott. Ezek az adatok jó egyezést mutatnak a területen kimutatható több éves klímaátlaggal, így valószínüsíthető, hogy a pollen proxy adatok nyomán készített utolsó 3000 évet átfogó éghajlati rekonstrukciónk megfelelő.

A radiokarbon adatokkal korolt környezettörténeti adataink alapján a Baláta-tó fejlődése jóval komplikáltabb annál, mint amelyet a recens növények jelenléte alapján állítottak fel (ősláp hipotézis) és további feldol- 
gozásokra van szükség, hogy a medence teljesebb holocén fejlődését fel tudjuk tárni, vagy megértsük, hogy miért nem rakódott le üledék a holocén első szakaszaiban ebben a jégkori szélbarázdában.

Ugyanakkor az már egyértelműen megállapítható, hogy a Baláta-tó és a Balaton (de még a Kis-Balaton) tavi rendszere között sem volt szoros hidrológiai, hidrogeológiai kapcsolat, mert a Balaton és a Kis Balaton kifejlödése, tavi rendszere már a holocén kezdetén is kialakult. Sőt a balatoni részmedencék, köztük a KisBalaton medencéjében kifejlődött legjelentősebb tavi vízborítás és vízfelület kiterjedése a középső-bronzkort követően már létrejött. Mind a nagy-bereki és mind a kis-balatoni részmedence területén igen jelentős, 106-108 méteres magasságot meghaladó vízállások kialakulását lehetett bizonyítani a bronzkor előtt is és a késő - bronzkor folyamán (SüMEGI et al. 2004, 2008). Mivel ezekben a magas vízállású szakaszokban - az eddigi adatok alapján - nem képződött üledék a Baláta-tó medencéjében így jelenleg kizárható a közvetlen hidrológiai kapcsolat a balatoni részmedencék és a balátai üledékgyűjtő medence között.

A környezettörténeti adatok azt jelzik, hogy a vizsgált területen az elmúlt 3000 év éghajlati változásai során az erdők összetétele többször erőteljesen megváltozott, de a terület alapvetően erdősült maradt és a legszárazabb-legmelegebb éghajlati szakaszokban is csak akkor szorult vissza az erdőborítás, ha az agárgazdálkodás érdekében a fákat kitermelték a területröl. Három jelentős felmelegedési ciklust lehetett kimutatni proxy adatok alapján (római és a viking optimum, valamint a XVIII. század második felében kialakult hőmérséklet-emelkedés).

A legerőteljesebb hatással a lápra a XIII. századi felmelegedés volt, ezt bizonyítja az ekkor kialakult tőzegégés is, de valószínü, hogy ebben is erőteljes szerepet játszhatott a lápot övező erdőterületek irtása, és az ennek nyomán lejátszódó mikroklíma változás, a lokális páratartalom erőteljes csökkenése. Ez a környezettörténeti adat a Baláta-tó lápos tavi rendszere és a környező erdőterületek közötti mikroklimatikus kapcsolat fontosságára hívja fel a figyelmet, és azt mutatja, hogy a láp hosszú távú védelmét nem oldhatjuk meg a környező erdőterületek védelme nélkül.

Ezt erősíti meg Borhidi Attila éghajlati kutatásai is, amikor rámutatott a száraz-mediterrán és a kontinentális éghajlati hatások szerepére a tó kiszáradásában, az 1940-es években, amikor is a lápot környező erdőkben igen jelentős háborús rablógazdálkodás folyt. Így a páratartalom megtartásában alapvető szerepet játszó, lápot övező erdőterületeket is megbontották és ennek nyomán a láp kiszáradása is felgyorsult.

Kiemelkedő jelentőségűek a jelenleg és közeljövőben zajló éghajlati változások hatásainak megelőzésében ezek a környezettörténeti adatok és klimatológiai vizsgálatok, mert a jelenleg zajló felmelegedés hatását csak úgy csökkenthetjük, ha a láp körül kialakult erdőket nem bolygatjuk meg és a láp partján zárt cserjeszinttel rendelkező puha és keményfás erdők kialakulását lehetővé tesszük, a lehető legszélesebb sávban. Ezzel a zárt erdőburokkal a láp felszínének kiszáradását, vízvesztését minimalizálhatjuk.

A késő-vaskori és császárkori felmelegedés növényzeti változásai is figyelemre méltóak voltak, mert egészen a Krisztus utáni III. századig a napjainkban jelentkező felmelegedést is meghaladó hőmérsékleti maximumok és $700 \mathrm{~mm}$ alatti éves csapadékbevétel ellenére is erdősült maradt a terület a késő-császárkori erdőirtásig, a pannoniai római agrárium és erdőgazdálkodás megváltozásáig.

\section{Irodalom}

BALOGH, M. 1983: A Velencei-tó nyugati medencéjének úszólápjai és hatásuk a tó vízminőségére. Kandidátusi értekezés, MTAVITUKI, Budapest, p.110.

BALOGH, M. 2000: Az úszólápi szukcesszió kérdései I. Kitaibelia 5. pp. 9-16.

Braun, M., Sümegl, P., Szücs, L. és Szöör, Gy. 1993: A kállósemjén Nagy-Mohos láp fejlődéstörténete (Lápképződés emberi hatásra és az ősláp hipotézis). Jósa András Múzeum Évkönyve, 3335. pp. 335-366.

Barber, K. E., Chambers, F. M., Maddy, D. \& Brew, J. 1994: A sensitive high resolution record of the Holocene climatic change from a raised bog in northern England. Holocene, 4. pp. 198-205.

BENNETT, K. D. 1992: PSIMPOLL - A quickBasic program that generates PostScript page description of pollen diagrams. - INQUA Commission for the study of the Holocene: working group on data handling methods, Newsletter 8. pp. 11-12.

BenNETT, K. D. 1994: Confidence intervals for age estimates and deposition times in late-Quaternary sediment sequences. The Holocene, 4. pp. 337-348.

Berglund, B.E. \& Ralska-Jasiewiczowa, M. 1986: Pollen analysis and pollen diagrams. pp. 455-484. In Berglund, B.E. ed. Handbook of Holocene palaeoecology and palaeohydrology. John Wiley and Sons Press, Chichester.

BIRKs, H. J. B. \& BIRKs, H. H. 1980: Quaternary palaeoecology. Edward Arnold Press, London.
BoRHIDI, A. 1968: Dynamical changes of free floating water-plant communities of different $\mathrm{N}$-sources in the Nature Reservation Area of Baláta-Pond - Acta Biologica Hungarica 19. p. 523.

BorHIDI, A. 1970: Ökologie, Weltbewerb und Zönologie des Schilfrohrs (Phragmites communis L.) und die Systematik der Brackröhrichte. Acta Botanica Hungarica, 16. pp. 1-12.

BorHIDI, A. \& JÁRAI-KomLÓDI, M. 1959a: Die Vegetation des Naturschutzgebietes des Baláta Sees. - Acta Bot. Acad. Sci. Hung. 5. pp. 259-320

BoRHIDI A. és J. Komlódı M. 1959b: A csapadék- és vízszint-ingadozás összefüggése a Baláta-tó természetvédelmi területén. (Zusammenhang der Niederschlags- und Wasserstandsfluktuation auf dem Naturschutzgebiet des BalátaTeiches). Időjárás, 63. pp. 225-229.

BorHIDI A. és J. KomLóDı M. 1960: A Baláta-tó növényvilága. Természettudományi Közlöny, 91. pp. 501-503.

Bronk Ramsey C. 2001: Development of the Radiocarbon Program OxCal. Radiocarbon 43. pp. 355-363.

CASAgRAnde, A. 1947: Classification and Identification of Soils. Proceeding of American Society of Civ. Engeeners. 78. pp. 783-810.

Dansgaard, W., Johnsen, S.J., Clausen, H. B., Dahl-Jensen, D. Gundenstrup, N. S., Hammer, C.J., Hvidberg, C. S., Steffensen, J.P., SveinbJörnsdottiR, A. E., Jouzel, J. \& Bond, G. 1993: Climate instability during the last interglacial period recorded in the GRIP ice core. Nature, 364. pp. 218-220. 
DÁniel, P. 2004: Geochemical analysis. pp. 52-57. Sümegi, P. - Gulyás, S. eds. 2004. The geohistory of Bátorliget Marshland. Archaeolingua Press, Budapest.

Davis, B., Brewer, S.,Stevenson, T. \& Juggins, S. 2001: High resolution from low resolution; a new method for time-series pollenclimate reconstruction and its application in investigating abrupt Holocene climate change in Southern Europe/Mediterranean. Abstracts of PAGES-PEPIII: Past Climate Variability Through Europe and Africa.

DEAN, W. E., 1974: Determination of carbonate and organic matter in calcareous sediments and sedimentary rocks by loss on ignition: Comparison with other methods. J. of Sed. Research 44: $242-248$.

FeldmanN, L. \& BirkHolz, B. 2002: Moor und Heidelandschaften in Norddentschland. Akademie für Geowissenschaften und Geotechnologien, Veröffentlichungen. 20. pp. 33-40.

Holzhauser, H., Magny, M. \& ZumbüHL, H. J. 2005: Glacier and lakelevel variations in west-central Europe over the last 3500 years. Holocene, 15. pp. 789-801

JAKAB G. és SümEGı P. 2004: A lágyszárú növények tőzegben található maradványainak határozója mikroszkópikus bélyegek alapján [Identifying of herbaceous plant remains from peat on the basis of microscopic features]. Kitaibelia 9, 93-129.

JAKAB, G. \& SüMEGI, P. 2005: The evolution of Nádas-tó at Nagybárkány in the light of the macorfossil finds. 67-77. In: Gál, E. - Juhász, I. - Sümegi, P. eds. Environmental Archaeology in North-Eastern Hungary. Varia Archaeologica Hungarica, XIX. Budapest.

JAKAB, G. \& SÜMEGI, P. 2007: The macrofossil remains from Balátató. pp. 331-334. In: Zatykó, Cs. - Juhász, I. - Sümegi, P. eds. 2007. Environmental Archaeology in Transdanubia (Hungary). Varia Archaeologica Hungarica sorozat XX. kötet, MTA Régészeti Intézet, Budapest

JAKAB, G., SÜMEGI, P. \& MAGYARI, E. 2004: A new palaeobotanical method for the description of Late Quaternary organic sediments (Miredevelopment pathways and palaeoclimatic records from S Hungary). Acta Geologica Hungarica, 47. pp. 1-37.

Grootes, P. M., Stuiver, M., J. W. C., White, J. W. C. Johnsen, S. \& JouzeL, J. 1993: Comparison of oxygen isotope records from the GISP2 and GRIP Greenland ice cores. Nature, 366. pp. 552 $-554$.

KASZA F. és MARIÁN M. 2001: A Baláta láp és gerinces állatvilága, különös tekintettel a madarakra. Natura Somogyensis 2. Kaposvár.

LAMB, H. H. 1995: Climate, history and the modern world. Routledge Press, London.

LÁszLó G. 1913: A balatonmelléki tőzeglápok és berkek. Magyar Királyi Földtani Intézet évi jelentése, Budapest.

LÁszLó G. és EmSzt K. 1911: Jelentés az 1905-1909 év folyamán eszközölt tőzeg és lápkutatásról, Magyar Királyi Földtani Intézet évi jelentése, Budapest.

LÁszló G. és Emszt K. 1915: Tőzeglápok és előfordulásuk Magyarországon. A Magyar Királyi Földtani Intézet Kiadványai, IV. p. 3-115. Budapest.

MACKERETH, F. J. H. 1966: Some chemical observations on post-glacial lake sediments. Philosophical Transactions of the Royal Society of London B 250: 165-213.

Magny, M., Mouthon, J. \& Ruffaldi, P. 1995: Late Holocene level fluctuations of the lake llay in Jura, France: sediment and mollusc evidence and climatic implications. Journal of Paleolimnology 13. pp. 219-229.

MAGnY, M. 2004: Holocene climatic variability as reflected by midEuropean lake-level fluctuations, and its probable impact on prehistoric human settlements. Quaternary International 113, 65-79.

MARIÁN M. 1957: A Baláta gerinces állatvilága. Somogyi Almanach I. Kaposvár.

MAROSı S. 1970: Belső-Somogy kialakulása és felszínalaktana. Akadémiai Kiadó, Budapest, p.169.

Reimer P.J., Bard, E., Bayliss A., Beck J. W., Blackwell, P. G., Bronk Ramsey, C., Buck, C. E., Cheng, H., Edwards, R. L., Friedrich, M., Grootes, P. M., Guilderson, T. P., Haflidason, H., Hajdas, I., Hatté, C., Heaton, T. J., Hogg, A. G., Hughen, K. A., Kaiser, K. F., Kromer, B., Manning, S. W., Niu, M., Reimer, R. W., Richards, D.
A., Scott, E. M., Southon, J. R., Turney C.S.M. \& VAn der Plicht, J. 2013: IntCal13 and MARINE13 radiocarbon age calibration curves 0-50000 years calBP. Radiocarbon 55(4). DOI: $10.2458 /$ azu_js_rc.55.16947

SÜMEGı P. 1996: Az ÉK-magyarországi löszterületek összehasonlító öskörnyezeti és sztratigráfiai értékelése. Kandidátusi értekezés, p.120. Debrecen.

SüMEGI P. 1998: Az utolsó 15000 év környezeti változásai és hatásuk az emberi kultúrákra Magyarországon. pp. 367 - 397. In: Ilon G. ed. A régésztechnikusok kézikönyve. Szombathely, Savaria Kiadványa.

SüMEGI P. 1999: Reconstruction of flora, soil and landscape evolution, and human impact on the Bereg Plain from late-glacial up to the present, based on palaeoecological analysis. pp. 173-204. In: Hamar, J. -Sárkány-Kiss, A. eds. The Upper Tisa Valley. Tiscia Monograph Series, Szeged.

SüMEGI P. 2001: A negyedidőszak földtanának és őskörnyezettanának alapjai. JATEPress, Szeged, p.262.

SüMEGI P. 2003: Régészeti geológia és történeti ökológia alapjai. JATEPress, Szeged, p.224.

SÜMEGI, P. 2004: The results of paleoenvironmental reconstruction and comparative geoarcheological analysis for the examined area. pp. 301-348. In: Sümegi, P.-Gulyás, S. eds. The geohistory of Bátorliget Marshland. Archaeolingua Press, Budapest.

SüMEGI, P. 2005: Loess and Upper Paleolithic environment in Hungary. Aurea Kiadó, Nagykovácsi, p.312.

SüMEGI, P. 2007: Description of the sampling location at Baláta-tó. pp. 322-324. In: Zatykó, Cs.-Juhász, I.-Sümegi, P. eds. 2005. Environmental Archaeology in Transdanubia (Hungary). Sümegi, P.-Magyari, E.-Daniel, P.-Hertelendi, E.-Rudner, E. 1999. A kardoskúti Fehér-tó negyedidőszaki fejlődéstörténetének rekonstrukciója. Földtani Közlöny, 129. pp. 479-519.

Sümegı P., Bodor E., Juhász I., Hunyadfalvi Z., Molnár S., Herbich K., SzegVÁRI G., IMRE, M. és Timár G. 2004: A balatoni déli autópálya régészeti lelöhelyeinek környezettörténeti feldolgozása. MUMOSZ III. Konferencia anyaga, Szombathely, pp. 399-420.

SÜMEGI, P., GulYÁs, S. \& JAKAB, G. 2008: Holocene paleoclimatic and paleohydrological changes in Lake Balaton as inferred from a complex quantitative environmental historical study of a lacustrine sequence of the Szigliget embayment. Documenta Praehistorica, XXXV. pp. 33-43.

SüMegI, P., JAKAB, G., MAJkut, P., TÖRÖcsiK, T. \& ZATYKó, Cs. 2009: Middle Age paleoecological and paleoclimatological reconstruction in the Carpathian Basin. Időjárás, 113. pp. 265-298.

StockmarR, J. 1971: Tablets with Spores used in Absolute Pollen Analysis. Pollen et Spores 13. pp. 615-621.

Stuiver, M., Grootes, P. M. \& Braziunas, T. F. 1993: The GISP2 $\delta^{18} \mathrm{O}$ Climate Record of the Past 16,500 Years and the Role of the Sun, Ocean, and Volcanoes. Quaternary Research, 44. pp. 341354.

SzABó P. 2002: „Erdők, erdészet, erdészettörténet”. Soproni Szemle 56 (4) pp. 390-392

SzABó, P. 2005: Woodland and Forests in Medieval Hungary. Archaeopress, Oxford.

Telforda, R. J., HeegaArd, E. \& Birks, H. J. B. 2004: All age-depth models are wrong: but how badly? Quaternary Science Reviews, 23. pp. 1-5

Troels-SMITH, J. 1955: Karakterisering af lose jordater. Danmarks Geologiske Undersogelse, 4(3): 10.

VADAY A. 2004: Kronológiai táblák. pp. 473-477. In: Visy, Zs. ed. Magyar régészet az ezredfordulón. Budapest.

VALANUS, A. 2008: Drawing the optimal dept-age curve on the basis of calibrated radiocarbon dates. Geochronometria, 31. pp. 1-5.

VENDEL M. 1959: A kőzetmeghatározás módszertana. Akadémiai kiadó, Budapest.

ZATYKó, Cs. 2007: Medieval settlement history of the Baláta Lake and its environs. 259-266. In: Zatykó, Cs. - Juhász, I. - Sümegi, P. eds. Environmental Archaeology of Transdanubia. Varia Archaeologica Hungarica XX. Budapest. 